\title{
Diet and feeding ecology of blue petrels Halobaena caerulea at Iles Kerguelen, Southern Indian Ocean
}

\author{
Yves Cherel $^{1, *}$, Pierrick Bocher $^{1,2}{ }^{,}$, Colette Trouvé ${ }^{1}$, Henri Weimerskirch ${ }^{1}$ \\ ${ }^{1}$ Centre d'Etudes Biologiques de Chizé, UPR 1934 du Centre National de la Recherche Scientifique, BP 14, \\ 79360 Villiers-en-Bois, France
}

${ }^{2}$ Laboratoire de Biologie et Environnement Marins, EA 1220 de l'Université de La Rochelle, 17026 La Rochelle Cedex, France

\begin{abstract}
The food and feeding ecology of the blue petrel Halobaena caerulea was investigated over 4 consecutive chick-rearing periods at Iles Kerguelen. In all years, blue petrels fed on a large diversity of crustaceans and fish, with a small proportion of squid and other organisms. Crustaceans ranked first by number $(98 \%)$ and second by reconstituted mass $(37 \%)$. The hyperiid Themisto gaudichaudii and the euphausiid Thysanoessa sp. were the dominant prey items, accounting each for $42 \%$ by number, and for 12 and $4 \%$ by mass of the diet, respectively. Other important crustacean prey were the Antarctic krill Euphausia superba ( $2 \%$ by number and $10 \%$ by mass) and the large shrimp Pasiphaea scotiae ( $<1$ and 5\%, respectively). Fish were minor items by number $(<1 \%)$ but, owing to their large size, they dominated the diet by reconstituted mass $(57 \%)$. Mesopelagic fish of the families Myctophidae (14\% by mass) and Melamphaidae $(12 \%)$ were the main fish prey together with the gempylid Paradiplospinus gracilis (19\%). Adult blue petrels use a 2-fold foraging strategy, performing short trips (ST, 2 d on average) and long trips (LT, 7 d) during the chick-rearing period. Birds fed more on T. gaudichaudii during ST and more on Thysanoessa sp. during LT. The subantarctic krill Euphausia vallentini were found in ST samples, and Antarctic krill and stomach oil were found in LT samples. Biogeography of the prey shows that blue petrels fed in a wide variety of marine habitats. During ST, they foraged in the kelp belt and over the shelf, but favoured oceanic waters in the vicinity of the archipelago. During LT, the occurrence of Antarctic krill indicates feeding in southern Antarctic waters, $>1000 \mathrm{~km}$ from the breeding colonies, but blue petrels also foraged on their way back to Iles Kerguelen from these distant foraging grounds to feed their chicks. A comparison of the stable carbon and nitrogen isotopic compositions of chick and adult feathers reveals that adult blue petrels fed at the same trophic level during the chick-rearing and moulting period, and that they renew their flight feathers in Antarctic waters.
\end{abstract}

KEY WORDS: Euphausia superba $\cdot$ Mesopelagic fish $\cdot$ Seabirds $\cdot$ Stable carbon isotopes $\cdot$ Stable nitrogen isotopes · Themisto gaudichaudii $\cdot$ Thysanoessa

\section{INTRODUCTION}

The blue petrel Halobaena caerulea is a small procellariiform species that is taxonomically closely related to the prions (genus Pachyptila). It is the sole member of the genus and inhabits the subantarctic and Antarctic zones of the Southern Ocean (Warham 1990). The species is circumpolar and nests colonially in bur-

\footnotetext{
*E-mail: cherel@cebc.cnrs.fr
}

rows at 6 locations close to the Antarctic polar front. The main population of blue petrels is in the southern Indian Ocean and at Diego Ramirez (Chile) with smaller numbers at Macquarie and South Georgia (Marchant \& Higgins 1990). At Iles Kerguelen, the species is numerous (100000 to 200000 pairs), and it breeds sympatrically with 3 different prion species: the fairy prion $P$. turtur and 2 large populations of thinbilled prions P. belcheri and Antarctic prions P. desolata (Weimerskirch et al. 1989). The species is wide- 
spread in subantarctic and Antarctic waters, and observations at sea suggest that breeders forage primarily in Antarctic waters during the chick-rearing period and that they disperse southwards at the end of the reproductive season to moult (Stahl et al. in press).

The diet of blue petrels was previously studied at 3 different localities during the breeding season. The species feed mainly on crustaceans, with fish and squid being of lesser importance in the diet. Depending on their availability in the area, the major crustacean prey are the subantarctic krill Euphausia vallentini at Marion Island (Steele \& Klages 1986), E. vallentini together with Thysanoessa sp. and the hyperiid Themisto gaudichaudii at Crozet (Ridoux 1994), and Antarctic krill Euphausia superba at South Georgia (Prince 1980). However, as Prince (1980) pointed out, mass analysis alone may significantly underestimate the importance of fish, which probably form the bulk of unidentifiable material and thus dominate over crustaceans in the food at South Georgia (Prince \& Morgan 1987). At Iles Kerguelen, almost nothing is known about the dietary habits of blue petrels (Marchant \& Higgins 1990), but the species showed a particular strategy of food provisioning for a seabird (Chaurand \& Weimerskirch 1994). During the chick-rearing period, adult birds regularly alternate short (ST) and long trips (LT), ST enabling them to increase the chick-feeding frequency at the expense of energy reserves built up during LT. Preliminary analysis of food indicated that undetermined amphipods, euphausiids and myctophid fish dominated both ST and LT samples, but some deep-water crustaceans were found in LT samples only. This led to the hypothesis that birds forage over oceanic waters during LT, with ST restricted to the Kerguelen shelf (Chaurand \& Weimerskirch 1994).

The main objectives of this work were, first, to study the food and feeding ecology of blue petrels breeding at Iles Kerguelen. An integrative programme (Interactions Oiseaux-Zooplancton [IOZ]) was developed to investigate the community of planktivorous petrels in relation to the marine environment during the breeding cycles 1994/95, 1995/96 and 1996/97. The present paper follows others devoted to the feeding habits of prions (Cherel et al. 2002, in this issue) and diving petrels (genus Pelecanoides) (Bocher et al. 2000). Prey species, chick-feeding frequency and food mass were recorded over the 3 chick-rearing periods. A special emphasis was the determination of the fish prey through the examination of otoliths and bones (for details see Cherel et al. 2000b) because fish found in food samples from blue petrels are extensively digested, and only a few individuals have been identified to the species level up to now (Prince 1980, Steele \& Klages 1986, Ridoux 1994). Second, we investigated during a fourth year (1998) the prey items collected during trips of known duration in order to determine and compare the marine resources consumed during ST and LT. The biogeography of the prey was thus used to give a first insight into the foraging grounds during both kinds of trips, the small size of blue petrels precluding the use of satellite tags.

We also focused on the foraging ecology during the inter-breeding period through stable isotopic analyses of adult flight feathers. Since keratin is metabolically inert after synthesis (Kelly \& Finch 1998), the stable carbon and nitrogen isotopic composition of feathers are markers that have the potential for investigating the birds' trophic relationships and foraging areas during the moulting period (Bocher et al. 2000, Cherel et al. 2000a). In adult blue petrels, as in many seabirds, flight feathers are synthesised after the breeding season, in February and March, before birds transiently return to their burrows in April and May (Fugler et al. 1987, Marchant \& Higgins 1990, Stahl et al. in press). Thus, a comparison of the stable isotope ratios of feathers from chicks (which moult in their burrows while being fed by their parents) with those from adults can give valuable information on foraging grounds of adult seabirds during chick rearing and moult, respectively.

\section{MATERIALS AND METHODS}

Study sites, birds and breeding success. Fieldwork was carried out during 4 consecutive summer seasons: the 3 years of the IOZ programme $(1994 / 95,1995 / 96$ and 1996/97) and a fourth year (1997/98) during which the food and feeding ecology during foraging trips of known duration (ST and LT) was investigated. The study colonies were located at Ile Mayes $\left(49^{\circ} 28^{\prime} \mathrm{S}\right.$, $69^{\circ} 57^{\prime} \mathrm{E}$ ) in the Golfe du Morbihan, eastern Kerguelen Archipelago (southern Indian Ocean) (Fig. 1), where a large population of blue petrels breeds.

During the 3 breeding seasons of the IOZ programme, 2 nearby colonies of blue petrels were used, one for investigating their foraging ecology and the other to study their demographic parameters. In the latter colonies, all birds were given individual leg bands, and the burrows were checked several times during a given year: first, during the prebreeding period to estimate the number of visited burrows and subsequently during the breeding season at laying, hatching and before fledging to estimate the hatching, fledging and breeding success. Between 207 and 233 burrows were monitored in the demographic colonies. Chicks were weighed and their wing measured a few days before fledging. In the dietary colonies, birds were studied each year during 10 to 12 consecutive days (Table 1) in mid-January, corre- 

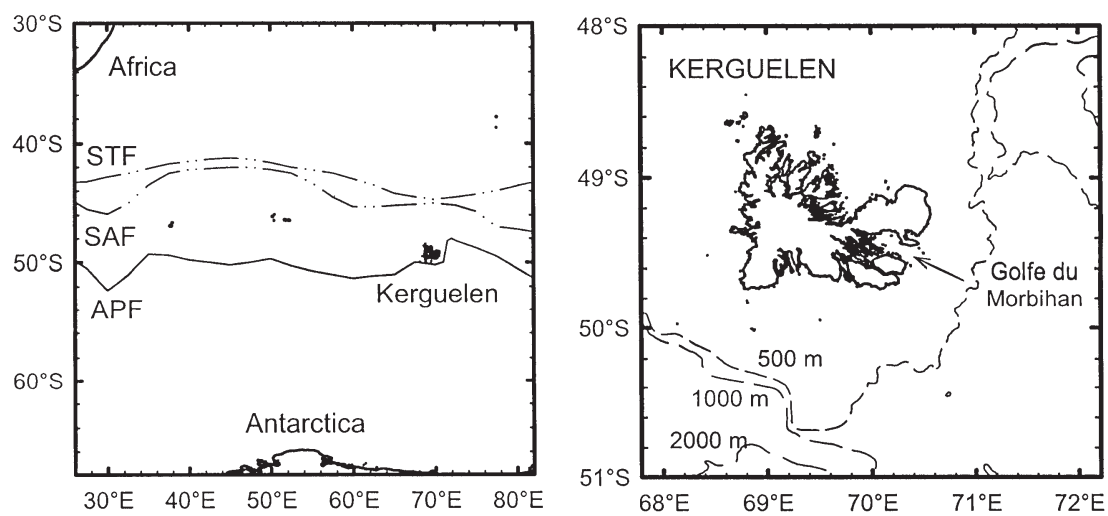

Fig. 1. Map of the Southern Indian Ocean showing the location of Kerguelen Islands. APF: Antarctic polar front; SAF: Subantarctic front; STF: Subtropical front tween the 2 successive weighings within a given night or between weighings at midnight and the following evening, was considered to result from a feeding event. However, food mass delivered by adults to chicks during a given night was calculated as the difference between a chick's body mass at 19:00 and 00:00 h only. Chick feeding frequency was calculated as the ratio of the number of nights with feedings (sum for all the chicks) to the total number of nights with weighings (sum for all the chicks) (Table 1). Note that $20.1 \%$ of feeding events occurred after midnight.

sponding to the middle of the chick-rearing period, which lasts about $50 \mathrm{~d}$ for this species (Marchant \& Higgins 1990).

In January 1998, the duration of foraging trips of individual birds was determined on 26 pairs of blue petrels during 24 consecutive nights ( 6 to 29 January). Each burrow was fitted with a trap door at the entrance to retain the adults (Weimerskirch et al. 1999). During the night, burrows were regularly inspected, and, if visits were detected, banded adults were caught and identified. The stomach contents of some of them were collected by spontaneous regurgitation at the end of the study period.

Food mass and feeding frequency. Twenty-three to 35 randomly selected chicks were monitored each year during the IOZ programme (Table 1). Burrows were marked with numbered wood stakes; in the case of deep burrows, an opening was dug out over the nesting chamber and covered with rock and earth slabs to facilitate access to the birds. Chicks were weighed (accuracy $\pm 2 \mathrm{~g}$ ) twice daily, before dusk at 19:00 $\mathrm{h}$ (local time), when adults were at sea, and at 00:00 h, when most birds visiting the colony had fed their chick. An increase in body mass of at least $2 \mathrm{~g}$, either be-
Dietary analyses. Blue petrels were caught either by mist netting at night or in burrows fitted with trap doors at the entrance to retain the adult before the chick was fed. Food samples were collected by spontaneous regurgitation at the time of capture. Since birds often began to regurgitate as soon as they hit the net or were handled, samples were only collected from birds that had not started regurgitating until they were inverted over a funnel (Steele \& Klages 1986). After food sampling, birds were weighed, measured and banded. No individual bird was sampled more than once in the study. Diet samples were immediately frozen at $-20^{\circ} \mathrm{C}$ and returned to Chizé, France, for analysis. In the laboratory, each sample was thawed overnight over a sieve so that the liquid fraction was separated from the solid items and collected in a graduated tube. The volumes of the liquid fraction, water and stomach oil, and mass of the solid fraction were measured. The solid fraction was then placed in a large, flat-bottomed tray and fresh remains were divided into broad prey classes (crustaceans, fish, cephalopods and others), which were weighed to estimate their proportions by fresh mass in the diet.

Table 1. Halobaena caerulea chick body mass, chick feeding frequency (nights with feeding events) and food mass brought by the adults to the chicks at night during 3 consecutive chick-rearing periods. Values are means \pm SD with ranges in parentheses

\begin{tabular}{|c|c|c|c|c|c|c|c|c|}
\hline \multirow{3}{*}{ Study period } & \multirow{3}{*}{$\begin{array}{c}\text { No. of } \\
\text { chicks } \\
\text { (begin-end) }\end{array}$} & \multicolumn{2}{|c|}{ Chick mass $(g)$} & \multirow{3}{*}{$\begin{array}{l}\text { Total no. } \\
\text { of nights }\end{array}$} & \multirow{2}{*}{\multicolumn{2}{|c|}{$\begin{array}{l}\text { Nights with } \\
\text { feeding events }\end{array}$}} & \multicolumn{2}{|c|}{ Food mass } \\
\hline & & & & & & & Mass & Samples \\
\hline & & Beginning & End & & $\mathrm{n}$ & $\%$ & (g) & (n) \\
\hline 16-27 Jan 1995 & $5 \quad 23-19$ & $154 \pm 31(106-238)$ & $159 \pm 22(110-208)$ & 247 & 112 & 45.3 & $45.9 \pm 17.8(2-102)$ & 91 \\
\hline 15-26 Jan 1996 & $6 \quad 32-27$ & $168 \pm 31(106-234)$ & $195 \pm 41(87-267)$ & 361 & 163 & 45.1 & $51.2 \pm 13.8(10-99)$ & 127 \\
\hline 11-20 Jan 1997 & $7 \quad 35-35$ & $163 \pm 33(62-226)$ & $170 \pm 35(74-260)$ & 350 & 142 & 40.6 & $48.5 \pm 21.1(2-136)$ & 115 \\
\hline \multirow[t]{2}{*}{ Total } & $90-81$ & $162 \pm 32(62-238)$ & $176 \pm 37(74-267)$ & 958 & 417 & 43.5 & $48.8 \pm 17.7(2-136)$ & 333 \\
\hline & & & & & \multicolumn{2}{|c|}{$\chi^{2}{ }_{2}=1.96, p=0.375^{\mathrm{a}}$} & \multicolumn{2}{|c|}{$F_{2,330}=2.42, \mathrm{p}=0.090^{\mathrm{a}}$} \\
\hline
\end{tabular}


Total numbers of common and rare prey items were counted in each sample. Prey were identified using keys and descriptions in Bellan-Santini \& Ledoyer (1974), Clarke \& Holmes (1987), Baker et al. (1990), Williams \& McEldowney (1990), Razouls (1994), Vinogradov et al. (1996) and Boltovskoy (1999), and by comparison with material held in our own reference collection. Thirty to 60 items (either intact specimens or intact eyes) of the main crustacean prey were randomly selected per dietary sample. Total length and eye diameter were determined using an ocular scale in a binocular microscope. Total length of amphipods, euphausiids and copepods was measured from the front of the eye to the tip of the uropods, from the tip of the rostrum to the tip of the uropods, and from the tip of the rostrum to the furca, respectively. Total length of amphipods and euphausiids was also estimated from eye diameter measurements by the use of allometric equations (Ridoux 1994, Cherel et al. unpubl.). The length of fish and cephalopods was estimated by the use of otolith or dentary length and lower rostral length, respectively. To estimate the composition by mass of the diet, the body mass of crustaceans, fish, cephalopods and other organisms was estimated from body length using published relationships (Adams \& Klages 1987, Hindell 1988, Mizdalski 1988, Huntley et al. 1989, Williams \& McEldowney 1990, Ridoux 1994) and our own equations. Where equations for certain species were not available, estimates were made from equations for closely related species or for species with a similar morphology. The reconstructed mass of each taxon for each sample was calculated from the average wet body mass for the species in the sample. The value was then multiplied by the number of individuals in the sample, and the resulting value was pooled with those calculated for the same taxon in the other samples. The calculated masses for all the different taxa were consequently pooled, and the reconstituted proportion by mass of each taxon was then calculated as its percentage of the total reconstituted mass.

Stable isotope analysis. Feathers were collected from intact wings of adults and fledglings killed by subantarctic skuas Catharacta antarctica lönnbergi at the beginning and the end of the breeding season, respectively. Before isotopic analysis, feathers were cleaned of surface contaminants using a 2:1 chloroform:ether rinse, air dried and cut with stainless steel scissors into small fragments. Food samples were freeze dried or dried in an oven at $+60^{\circ} \mathrm{C}$ and ground to a fine powder in an analytical mill. Lipids were then removed using a Soxhlet apparatus with chloroform solvent for 4 to $6 \mathrm{~h}$.

Stable carbon and nitrogen isotopes were assayed on $1 \mathrm{mg}$ subsamples of homogenised materials by loading them into tin cups and combusting them at $1800^{\circ} \mathrm{C}$ in a
Robo-Prep elemental analyser. Resultant $\mathrm{CO}_{2}$ and $\mathrm{N}_{2}$ gases were then analysed using an interfaced Europa 20:20 continuous-flow isotope ratio mass spectrometer with every 5 unknowns separated by 2 laboratory standards. Stable isotope abundances were expressed in $\delta$ notation as the deviation from standards in parts per thousand (\%) according to the following equation:

$$
\delta X=\left[\left(R_{\text {sample }} / R_{\text {standard }}\right)-1\right] \times 1000
$$

where $X$ is ${ }^{13} \mathrm{C}$ or ${ }^{15} \mathrm{~N}$ and $R$ is the corresponding ratio, ${ }^{13} \mathrm{C} /{ }^{12} \mathrm{C}$ or ${ }^{15} \mathrm{~N} /{ }^{14} \mathrm{~N}$. The $R_{\text {standard }}$ values were based on the PeeDee Belemnite standard for ${ }^{13} \mathrm{C}$ and atmospheric $\mathrm{N}_{2}$ (air) for ${ }^{15} \mathrm{~N}$. Replicate measurements of internal laboratory standards (albumen) indicate measurement errors of \pm 0.1 and $\pm 0.3 \%$ o for stable carbon and nitrogen isotope measurements, respectively.

Statistical analysis. Data were analysed statistically using SYSTAT 9 for WINDOWS (SPSS Inc., Chicago, Illinois, USA). Values are means $\pm \mathrm{SD}$, with significance set at the 0.05 level.

\section{RESULTS}

\section{Food mass and feeding frequency}

Chicks of blue petrels were fed at least 1 meal by their parents on $44 \%$ of nights during the middle of the nesting period, with no significant differences between the 3 years. When fed, chicks received on average $49 \mathrm{~g}$ of food night ${ }^{-1}$, with again no significant inter-annual differences (Table 1). The decrease in the number of chicks to the end of the study periods in January 1995 and 1996 was due mainly to predation by subantarctic skuas on chicks located in shallow burrows. When taking into account the chicks followed during the whole study period only, the overall mass gain of chicks was positive $(15 \pm 35 \mathrm{~g})$ in $10 \mathrm{~d}$, with significant differences between years $(-3 \pm 28,33 \pm 37$ and $11 \pm$ $30 \mathrm{~g}$ for summers 1995, 1996 and 1997, respectively, 1 -way ANOVA, $F_{2,76}=7.62, \mathrm{p}=0.001$ ). The large range in mass of the chicks was due to the $2 \mathrm{wk}$ delay in the timing of the breeding cycle between early and late pairs of blue petrels (Fugler et al. 1987, Weimerskirch et al. 1989, Y.C. et al. unpubl.).

The mean adult body mass (after regurgitation) of blue petrels was $198 \mathrm{~g}$ and did not differ significantly between years $\left(F_{2,100}=1.20, \mathrm{p}=0.306\right)$. The wet mass of the 105 food samples averaged $24 \mathrm{~g}$, with significant differences between years $\left(F_{2,102}=3.85, \mathrm{p}=0.024\right)$, the food samples collected in 1995 being heavier than those collected in 1997 (post hoc Tukey's HSD multiple comparison test, $\mathrm{p}=0.019$ ) (Table 2). The mass of dietary samples was lower than that of the food mass 
Table 2. Halobaena caerulea body mass (after regurgitation), mass of food samples and broad prey class composition of the diet during 3 consecutive chick-rearing periods. Values are means \pm SD with ranges in parentheses

\begin{tabular}{|c|c|c|c|c|c|c|c|c|}
\hline \multirow{2}{*}{$\begin{array}{l}\text { Study } \\
\text { period }\end{array}$} & \multicolumn{2}{|l|}{ Birds } & \multicolumn{2}{|c|}{ Food sample mass } & \multicolumn{4}{|c|}{ Prey class (\% by fresh mass) } \\
\hline & Mass (g) & Ind. (n) & Mass (g) & Samples (n) & Crustaceans & Fish & Cephalopods & Others \\
\hline 1995 & $196 \pm 14(174-223)$ & 30 & $28.5 \pm 11.0(11.3-49.8)$ & 30 & 66.5 & 28.9 & 4.0 & 0.6 \\
\hline 1996 & $196 \pm 15(168-220)$ & 39 & $23.9 \pm 10.0(7.0-48.3)$ & 39 & 52.0 & 44.6 & 3.2 & 0.2 \\
\hline 1997 & $204 \pm 27(154-268)$ & 34 & $21.3 \pm 11.0(5.4-40.9)$ & 36 & 67.7 & 32.0 & 0.2 & 0.1 \\
\hline Total & $198 \pm 20(154-268)$ & 103 & $24.3 \pm 10.9(5.4-49.8)$ & 105 & 61.4 & 35.8 & 2.5 & 0.3 \\
\hline
\end{tabular}

measured by weighing chicks because spontaneous regurgitation is not a very effective way to collect the whole stomach content of petrels (Klages \& Cooper 1992, Cherel et al. 2002).

\section{Diet}

Blue petrels fed mainly on crustaceans (61 and $37 \%$ by fresh and reconstituted masses of the overall diet, respectively) and on fish (36 and $57 \%$ ), while squids (3 and $2 \%$ ) and other organisms (mainly the salp Salpa thompsoni) (<1 and $4 \%$ ) were minor items (Tables 2 $\& 3)$. The proportions by fresh mass of crustaceans and fish were similar for 1995 and 1997, but blue petrels relied less on crustaceans and more on fish in 1996 (Table 2). Crustaceans occurred in all samples. They dominated by number and by fresh mass in 100 and $60 \%(n=63)$ of the samples, respectively. Fish were found in $81 \%$ of the samples and they dominated by fresh mass in $39 \%(n=41)$ of them. Finally, cephalopods were the major prey by mass in 1 sample. Note, however, that the most important squid taxon, Oegopsid A (Table 3), consists only of eye lenses of the same large diameter, suggesting that, as in South Georgia (Prince 1980), birds scavenged on squids too large to be swallowed whole. Stomach oil was found in $66 \%$ ( $\mathrm{n}=69$ ) of the regurgitations.

A total of 17325 prey items was recovered from 105 samples collected in 1995, 1996 and 1997. There were 17021 crustaceans $(98.2 \%), 163$ fish $(0.9 \%), 17$ squids $(0.1 \%)$ and 124 other organisms (polychaetes and salps) $(0.7 \%)$. Overall, 25 species of crustaceans, 15 of fish, 1 of squid, 2 of polychaetes and 1 of salp were identified (Table 3). By number, the diet was dominated by the hyperiid amphipod Themisto gaudichaudii and the euphausiid Thysanoessa sp., which occurred in most of the samples (94 and $65 \%$, respectively) and each accounted for $42 \%$ of the total number of prey. Owing to their small size, however, their importance by reconstituted mass was lower (12 and $4 \%$, respectively). Two large crustacean species were also significant items by reconstituted mass: the Ant- arctic krill Euphausia superba (2\% by number and $10 \%$ by mass) and the shrimp Pasiphaea scotiae ( $<1$ and $5 \%$ ). Other common crustacean prey ( $>1 \%$ by number) were Euphausia vallentini, the gammarid Polycheria kergueleni, and the hyperiids Cyllopus magellanicus and Vibilia antarctica (Table 3).

Themisto gaudichaudii prevailed by number and by mass in $45 \%(n=47)$ and $19 \%(n=20)$ of the samples, respectively. It was the dominant crustacean prey in $1996(41 \%$ by reconstituted mass of the crustacean diet) and 1997 (37\%), and the second item (19\%) in 1995 (Fig. 2). Overall, 2 size classes of T. gaudichaudii were eaten by blue petrels: small individuals (3 to $14 \mathrm{~mm}$ total length), which were the dominant size class (63\% of the total number of $T$. gaudichaudii) with a mode at 9 to $10 \mathrm{~mm}$, and larger individuals (15 to $34 \mathrm{~mm}$ ) with a mode at 18 to $19 \mathrm{~mm}$ (Fig. 3). Large variations in the size of $T$. gaudichaudii were observed between the 3 years $(10.5 \pm 4.9,15.6 \pm 5.5$ and $15.5 \pm$ $6.8 \mathrm{~mm}, \mathrm{n}=821,830$ and 574 for 1995, 1996 and 1997, respectively, 1 -way ANOVA, $F_{2,2222}=209.40$, p < 0.0001), amphipods being smaller in 1995 than in 1996 and 1997 (post hoc Tukey's HSD multiple comparison test, all $\mathrm{p}<0.0001)$, with no differences between 1996 and 1997 ( $p=0.907$ ). Accordingly, length-frequency distributions were significantly different between years (Kolmogorov-Smirnov, all p < 0.0001). The small size class accounted for 93, 44 and $40 \%$ of the total number of T. gaudichaudii in 1995, 1996 and 1997, respectively, with a concomitant increase in the number of larger individuals during the study period (Fig. 3). Length-frequency distributions of small individuals were identical in 1995 and 1996 (Kolmogorov-Smirnov, $\mathrm{p}=0.085$ ) but differed in 1997 (both $\mathrm{p}<0.0001$ ), amphipods being slightly smaller in 1997 (data not shown).

The second main crustacean prey, Thysanoessa sp., prevailed by number and by mass in $40 \%(\mathrm{n}=42)$ and $8 \%(n=8)$ of the samples, respectively. Its importance in the diet of blue petrels was relatively constant throughout the 3 years, accounting for 9, 14 and $12 \%$ by mass of the crustacean diet in 1995, 1996 and 1997 , respectively (Fig. 2). Only 1 size class of Thysanoessa 
Table 3. Halobaena caerulea. Frequency of occurrence, number, reconstituted mass and length of prey items recovered from stomach contents during chick-rearing (total for all 105 samples pooled)

\begin{tabular}{|c|c|c|c|c|c|c|c|c|c|}
\hline \multirow[t]{2}{*}{ Prey species } & \multicolumn{2}{|c|}{ Occurrence in stomachs } & \multicolumn{2}{|c|}{ Number } & \multicolumn{2}{|c|}{ Reconstituted mass } & \multicolumn{3}{|c|}{ Body length (mm) } \\
\hline & $\mathrm{n}$ & $\%$ & $\mathrm{n}$ & $\%$ & $\mathrm{n}$ & $\%$ & Mean & Range & $\mathrm{n}$ \\
\hline Crustaceans & 105 & 100.0 & 17021 & 98.2 & 860.9 & 37.4 & & & \\
\hline \multicolumn{10}{|l|}{ Euphausiacea } \\
\hline Euphausia superba & 37 & 35.2 & 361 & 2.1 & 236.7 & 10.3 & $46.8 \pm 9.7$ & $26.1-63.7$ & 224 \\
\hline Euphausia vallentini & 9 & 8.6 & 290 & 1.7 & 18.1 & 0.8 & $22.7 \pm 3.5$ & $14.8-28.5$ & 101 \\
\hline Euphausia triacantha & 1 & 1.0 & 1 & $<0.1$ & $<0.1$ & $<0.1$ & $26.7 \pm 5.1$ & $19.6-40.4$ & 38 \\
\hline Euphausia sp. & 15 & 14.3 & 65 & 0.4 & 9.4 & 0.4 & 19.3 & & 1 \\
\hline Thysanoessa macrura/vicina & 68 & 64.8 & 7293 & 42.1 & 103.0 & 4.5 & $14.6 \pm 1.6$ & $9.8-21.1$ & 1380 \\
\hline \multicolumn{10}{|l|}{ Decapoda } \\
\hline Pasiphae scotiae & 34 & 32.4 & 42 & 0.2 & 111.4 & 4.8 & $98.3 \pm 11.3$ & 73.6-119.3 & 39 \\
\hline \multicolumn{10}{|l|}{ Mysida } \\
\hline Unidentified mysid & 1 & 1.0 & 1 & $<0.1$ & 2.5 & 0.1 & 64.6 & & 1 \\
\hline \multicolumn{10}{|l|}{ Isopoda } \\
\hline Unidentified isopods & 4 & 3.8 & 4 & $<0.1$ & $<0.1$ & $<0.1$ & 7.2 & & 1 \\
\hline \multicolumn{10}{|l|}{ Amphipoda } \\
\hline Polycheria kergueleni & 8 & 7.6 & 429 & 2.5 & 1.4 & 0.1 & $6.3 \pm 0.8$ & $4.5-7.9$ & 89 \\
\hline Сyphocaris richardi & 8 & 7.6 & 9 & $<0.1$ & 2.1 & 0.1 & $28.7 \pm 1.8$ & $27.5-31.3$ & 3 \\
\hline Eurythenes gryllus & 3 & 2.9 & 3 & $<0.1$ & 15.0 & 0.7 & & & \\
\hline Eurythenes obesus & 9 & 8.6 & 9 & $<0.1$ & 3.3 & 0.1 & $36.0 \pm 4.2$ & $30.8-43.1$ & 7 \\
\hline Eurythenes sp. & 2 & 1.9 & 2 & $<0.1$ & 0.8 & $<0.1$ & & & \\
\hline Uristes gigas & 1 & 1.0 & 1 & $<0.1$ & $<0.1$ & $<0.1$ & 11.4 & & 1 \\
\hline Parandania boecki & 1 & 1.0 & 1 & $<0.1$ & $<0.1$ & $<0.1$ & & & \\
\hline Cyllopus lucasii & 6 & 5.7 & 7 & $<0.1$ & 0.4 & $<0.1$ & $15.8 \pm 1.4$ & $14.5-17.7$ & 4 \\
\hline Cyllopus magellanicus & 70 & 66.7 & 429 & 2.5 & 24.1 & 1.0 & $14.0 \pm 3.1$ & $3.8-17.7$ & 255 \\
\hline Vibilia antarctica & 60 & 57.1 & 610 & 3.5 & 18.0 & 0.8 & $12.1 \pm 1.5$ & $6.8-15.8$ & 245 \\
\hline Hyperiella antarctica & 22 & 21.0 & 73 & 0.4 & 0.7 & $<0.1$ & $8.1 \pm 1.4$ & $5.4-11.4$ & 45 \\
\hline Hyperoche luetkenides & 13 & 12.4 & 36 & 0.2 & 1.5 & 0.1 & $12.7 \pm 1.5$ & $10.7-17.3$ & 20 \\
\hline Themisto gaudichaudii & 99 & 94.3 & 7309 & 42.2 & 286.8 & 12.5 & $13.3 \pm 6.4$ & $2.8-37.7$ & 2225 \\
\hline Primno macropa & 7 & 6.7 & 15 & $<0.1$ & 1.1 & $<0.1$ & $14.3 \pm 3.3$ & $7.5-19.7$ & 11 \\
\hline Unidentified amphipods & 8 & 7.6 & 10 & $<0.1$ & 0.6 & $<0.1$ & & & \\
\hline \multicolumn{10}{|l|}{ Copepoda } \\
\hline Calanus simillimus & 1 & 1.0 & 1 & $<0.1$ & $<0.1$ & $<0.1$ & 3.4 & & 1 \\
\hline Rhincalanus gigas & 1 & 1.0 & 1 & $<0.1$ & $<0.1$ & $<0.1$ & 5.8 & & 1 \\
\hline Drepanopus pectinatus & 1 & 1.0 & 1 & $<0.1$ & $<0.1$ & $<0.1$ & 2.1 & & 1 \\
\hline Paraeuchaeta antarctica & 1 & 1.0 & 2 & $<0.1$ & $<0.1$ & $<0.1$ & 8.7 & & 1 \\
\hline Heterorhabdus austrinus & 1 & 1.0 & 1 & $<0.1$ & $<0.1$ & $<0.1$ & & & \\
\hline Candacia maxima & 1 & 1.0 & 1 & $<0.1$ & $<0.1$ & $<0.1$ & & & \\
\hline \multicolumn{10}{|l|}{ Cirripedia } \\
\hline Lepas australis (cypris larva) & 1 & 1.0 & 1 & $<0.1$ & $<0.1$ & $<0.1$ & 2.5 & & 1 \\
\hline Crustacea sp. A & 2 & 1.9 & 2 & $<0.1$ & 2.6 & 0.1 & & & \\
\hline Unidentified crustaceans & 11 & 10.5 & 11 & $<0.1$ & 21.2 & 0.9 & & & \\
\hline Fish & 85 & 81.0 & 163 & 0.9 & 1307.3 & 56.8 & & & \\
\hline \multicolumn{10}{|l|}{ Microstomatidae } \\
\hline ?Nansenia antarctica & 1 & 1.0 & 1 & $<0.1$ & 52.5 & 2.3 & & & \\
\hline \multicolumn{10}{|l|}{ Bathylagidae } \\
\hline Bathylagus tenuis & 1 & 1.0 & 1 & $<0.1$ & 20.9 & 0.9 & & & \\
\hline \multicolumn{10}{|l|}{ Paralepididae } \\
\hline Arctozenus risso & 3 & 2.9 & 3 & $<0.1$ & 80.4 & 3.5 & 274.0 & & 1 \\
\hline Unidentified Paralepididae & 1 & 1.0 & 1 & $<0.1$ & 26.8 & 1.2 & & & \\
\hline \multicolumn{10}{|l|}{ Myctophidae } \\
\hline Electrona antarctica & 12 & 11.4 & 14 & $<0.1$ & 65.0 & 2.8 & $85.3 \pm 5.2$ & $75.9-90.6$ & 7 \\
\hline Electrona carlsbergi & 13 & 12.4 & 14 & 0.1 & 121.6 & 5.3 & $65.8 \pm 8.1$ & $55.4-77.6$ & 6 \\
\hline Electrona subaspera & 1 & 1.0 & 1 & $<0.1$ & 12.2 & 0.5 & 87.4 & & 1 \\
\hline Gymnoscopelus microlampas & 2 & 1.9 & 2 & $<0.1$ & 26.1 & 1.1 & 98.2 & & 1 \\
\hline Gymnoscopelus sp. & 2 & 1.9 & 2 & $<0.1$ & 14.1 & 0.6 & & & \\
\hline
\end{tabular}


Table 3 (continued)

\begin{tabular}{|c|c|c|c|c|c|c|c|c|c|}
\hline \multirow[t]{2}{*}{ Prey species } & \multicolumn{2}{|c|}{ Occurrence in stomachs } & \multicolumn{2}{|c|}{ Number } & \multicolumn{2}{|c|}{ Reconstituted mass } & \multicolumn{3}{|c|}{ Body length (mm) } \\
\hline & $\mathrm{n}$ & $\%$ & $\mathrm{n}$ & $\%$ & $\mathrm{n}$ & $\%$ & Mean & Range & $\mathrm{n}$ \\
\hline \multicolumn{10}{|l|}{ Myctophidae (continued) } \\
\hline Krefftichthys anderssoni & 19 & 18.1 & 23 & 0.1 & 27.0 & 1.2 & $49.8 \pm 4.4$ & $42.1-55.3$ & 7 \\
\hline Protomyctophum andriashevi & 1 & 1.0 & 1 & $<0.1$ & 1.6 & $<0.1$ & & & \\
\hline Protomyctophum bolini & 19 & 18.1 & 27 & 0.2 & 24.8 & 1.1 & $40.9 \pm 3.1$ & $34.7-44.4$ & 9 \\
\hline Protomyctophum choriodon & 1 & 1.0 & 1 & $<0.1$ & 1.0 & $<0.1$ & & & \\
\hline Protomyctophum sp. & 2 & 1.9 & 2 & $<0.1$ & 2.0 & $<0.1$ & & & \\
\hline Unidentified Myctophidae & 17 & 16.2 & 21 & 0.1 & 22.6 & 1.0 & & & \\
\hline Muraenolepididae & & 0.0 & & & & & & & \\
\hline Muraenolepis marmoratus & 3 & 2.9 & 3 & $<0.1$ & 62.6 & 2.7 & 204.4 & $203.9-204.8$ & 2 \\
\hline \multicolumn{10}{|l|}{ Melamphaidae } \\
\hline Poromitra crassiceps & 1 & 1.0 & 1 & $<0.1$ & 19.8 & 0.9 & & & \\
\hline Sio nordenskjöldii & 5 & 4.8 & 5 & $<0.1$ & 99.0 & 4.3 & & & \\
\hline Melamphaidae sp. A & 4 & 3.8 & 4 & $<0.1$ & 125.7 & 5.5 & & & \\
\hline Melamphaidae sp. B & 1 & 1.0 & 1 & $<0.1$ & 31.3 & 1.4 & & & \\
\hline \multicolumn{10}{|l|}{ Nototheniidae } \\
\hline Unidentified Nototheniidae & 1 & 1.0 & 1 & $<0.1$ & 1.0 & $<0.1$ & & & \\
\hline \multicolumn{10}{|l|}{ Gempylidae } \\
\hline Paradiplospinus gracilis & 19 & 18.1 & 19 & $<0.1$ & 447.5 & 19.5 & 283.1 & & 1 \\
\hline Unidentified fish & 15 & 14.3 & 15 & $<0.1$ & 21.9 & 1.0 & & & \\
\hline Cephalopods & 15 & 14.3 & 17 & 0.1 & 48.1 & 2.1 & & & \\
\hline \multicolumn{10}{|l|}{ Onychoteuthidae } \\
\hline Kondakovia longimana & 1 & 1.0 & 1 & $<0.1$ & 7.2 & 0.3 & 55.3 & & 1 \\
\hline Oegopsida sp. A & 6 & 5.7 & 7 & $<0.1$ & 25.8 & 1.1 & & & \\
\hline Unidentified squids & 9 & 8.6 & 9 & $<0.1$ & 15.1 & 0.7 & & & \\
\hline Others & 30 & 28.6 & 124 & 0.7 & 84.0 & 3.7 & & & \\
\hline \multicolumn{10}{|l|}{ Polychaeta } \\
\hline Platynereis australis & 1 & 1.0 & 1 & $<0.1$ & $<0.1$ & $<0.1$ & & & \\
\hline Tomopteris sp. & 1 & 1.0 & 1 & $<0.1$ & $<0.1$ & $<0.1$ & & & \\
\hline \multicolumn{10}{|l|}{ Salpidae } \\
\hline Salpa thompsoni & 29 & 27.6 & 122 & 0.7 & 83.9 & 3.6 & $16.0 \pm 4.3$ & $9.4-25.2$ & 45 \\
\hline Total & 105 & & 17325 & 100.0 & 2300.4 & 100.0 & & & \\
\hline
\end{tabular}

sp. was found, with a mode at 13 to $14 \mathrm{~mm}$ (Fig. 4). The size of the euphausiid varied little but significantly over years $(14.6 \pm 2.1,14.5 \pm 1.4$ and $14.8 \pm 1.4 \mathrm{~mm}, \mathrm{n}=$ 255, 607 and 518 for 1995, 1996 and 1997, respectively,

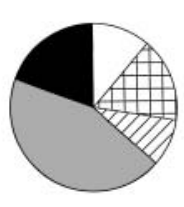

1995

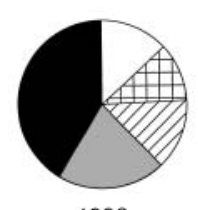

1996

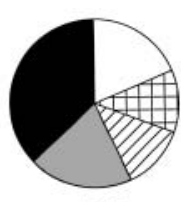

1997

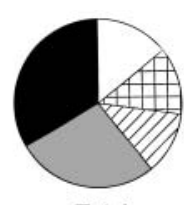

Total Themisto gaudichaudii $\square$ Euphausia superba
VIIIA Thysanoessa sp. $\quad$ Pasiphae scotiae $\square$ Other crustaceans

Fig. 2. Halobaena caerulea. Composition by reconstituted mass of the crustacean diet during 3 consecutive chickrearing periods 1-way ANOVA, $\left.F_{2,1377}=4.90, \mathrm{p}=0.008\right)$, as did its length-frequency distributions (Kolmogorov-Smirnov, all $\mathrm{p}<0.008)$.

Antarctic krill Euphausia superba prevailed by number and by mass in $6 \%(n=6)$ and $17 \%(n=18)$ of the samples, respectively. It was the main crustacean prey in 1995 (44\% by reconstituted mass of the crustacean diet) and the second item in 1996 (21\%) and 1997 (20\%) (Fig. 2). The size of Antarctic krill varied significantly over years $(53.2 \pm 4.4,42.4 \pm 11.0$ and $43.2 \pm 8.7 \mathrm{~mm}, \mathrm{n}=86,67$ and 71 for 1995, 1996 and 1997, respectively, 1 -way ANOVA, $F_{2,221}=42.32$, p < 0.0001), E. superba being larger in 1995 than in 1996 and 1997 (post hoc Tukey's HSD multiple comparison test, all $\mathrm{p}<0.0001)$. Length-frequency distributions were significantly different between years (Kolmogorov-Smirnov, all $\mathrm{p}<0.0001$ ). Blue petrels fed on only 1 large size class (mode at 50 to $52 \mathrm{~mm}$ ) in 1995, and on 2 distinct size classes in 1996 (mode at 26 to 28 and 


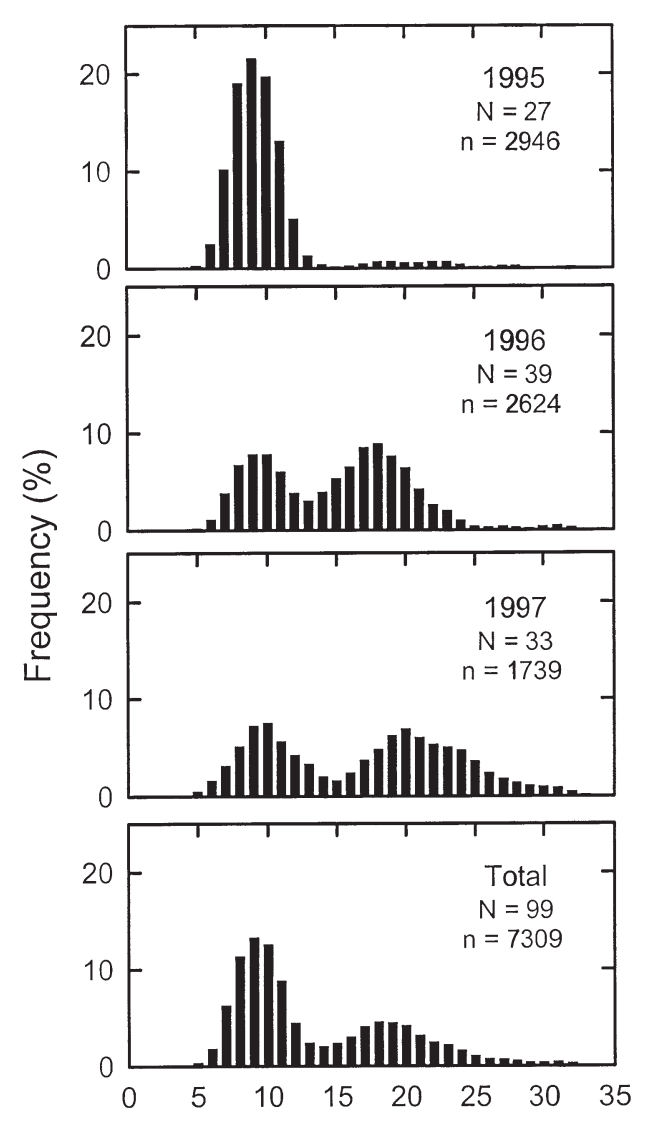

Themisto gaudichaudii total length ( $\mathrm{mm}$ )

Fig. 3. Length-frequency distribution of the hyperiid Themisto gaudichaudii in the diet of Halobaena caerulea during 3 consecutive chick-rearing periods. $\mathrm{N}$ : number of food samples; $\mathrm{n}$ : number of individuals

48 to $50 \mathrm{~mm}$ ) and 1997 (mode at 34 to 36 and 50 to $52 \mathrm{~mm}$ ) (Fig. 5). Note that the smaller size class was found in only 1 food sample in 1996 and in 4 samples in 1997. Excluding the smaller individuals, the body length of large E. superba $(>42 \mathrm{~mm})$ was different between years $\left(F_{2,154}=5.00, \mathrm{p}=0.008\right)$, krill being larger in 1995 than in 1996 (post hoc Tukey's HSD multiple comparison test, $\mathrm{p}=0.004$ ).

Blue petrels fed on a large diversity of fish. No species was a significant prey by number but, owing to their large sizes, 11 fish species each accounted for more than $1 \%$ of the diet by reconstituted mass (Table 3). At the species level, the commonest prey was the gempylid Paradiplospinus gracilis (12 and $34 \%$ of the fish diet by number and reconstituted mass, respectively), but, at the family level, myctophids (66 and $24 \%$ ) and melamphaids ( 7 and $21 \%$ ) were also important items (Fig. 6). Four myctophids were commonly encountered: Protomyctophum bolini $(17 \%$ of the fish prey), Krefftichthys anderssoni (14\%), Elec-

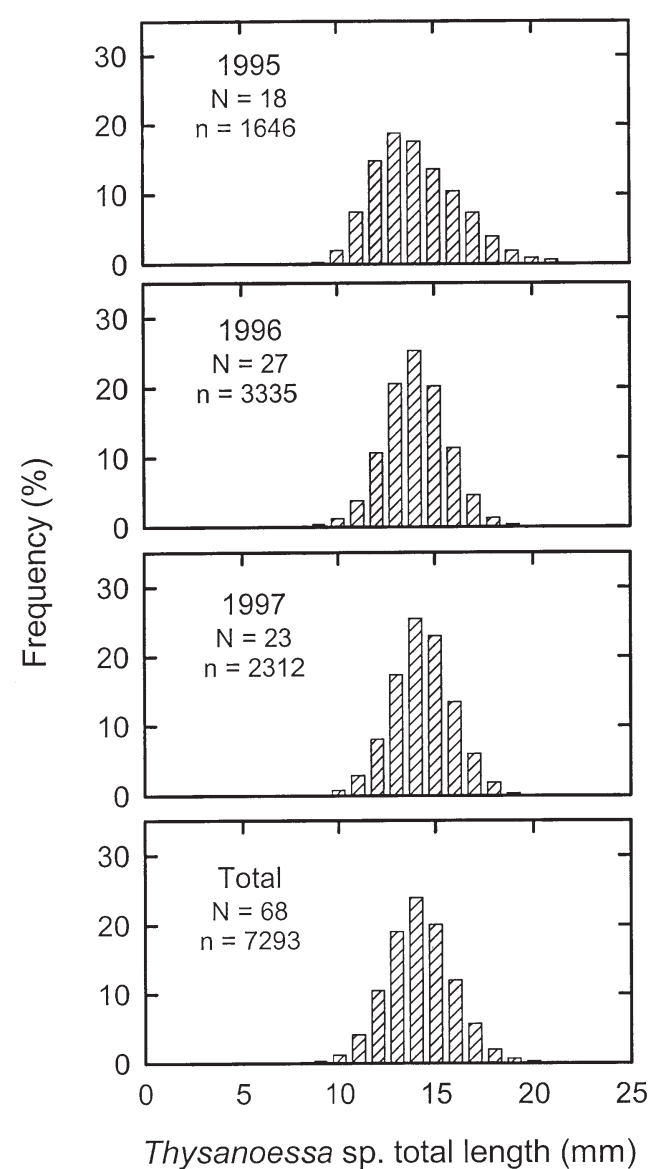

Fig. 4. Length-frequency distribution of the euphausiid Thysanoessa sp. in the diet of Halobaena caerulea during 3 consecutive chick-rearing periods. N: number of food samples; n: number of individuals

trona antarctica (9\%) and E. carlsbergi (9\%). The fish diet was similar in 1996 and 1997, but no $P$. gracilis was found in 1995, a year during which melamphaids were the main fish prey (54\% by mass) (Fig. 6).

Since blue petrels returned to their burrows outside the breeding season (after moult, in April and May), we tried to collect food samples at that time in 1995. Most of the birds had empty stomachs. Among 10 samples, only 4 contained a significant amount of food (6.7 to $26.0 \mathrm{~g}$ ). Interestingly, Euphausia vallentini occurred in the contents of all 4 stomachs and the species formed, by far, the bulk of the diet ( $\mathrm{n}=737,95 \%$ by number).

\section{ST and LT}

In January 1998, the distribution of durations of adult foraging trips was bimodal (modes at 2 and 6 to $8 \mathrm{~d}$ ) (Fig. 7). We separated trips into ST (1 to 3 d) and LT (>3 d) because food analysis (see below) clearly indi- 


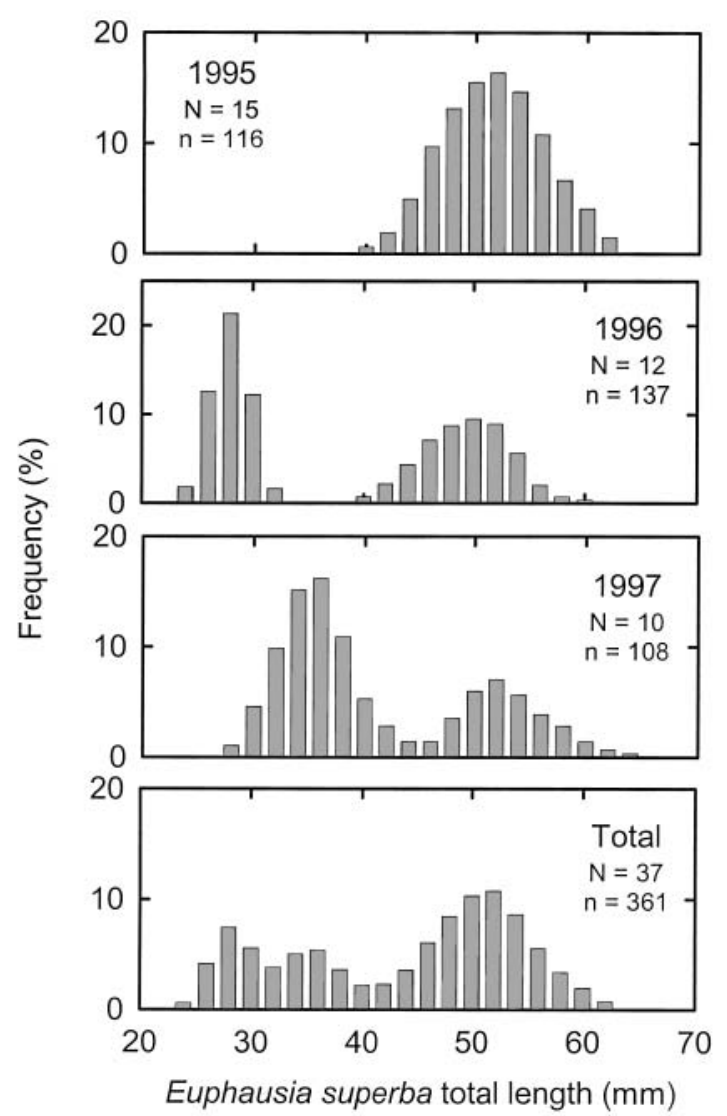

Fig. 5. Length-frequency distribution of the Antarctic krill Euphausia superba in the diet of Halobaena caerulea during 3 consecutive chick-rearing periods. $\mathrm{N}$ : number of food samples; $\mathrm{n}$ : number of individuals

cated that the uncommon foraging trips of $4 \mathrm{~d}$ were LT. On average, the duration of ST and LT was $2.0 \pm 0.6 \mathrm{~d}$ $(\mathrm{n}=57)$ and $6.9 \pm 1.5 \mathrm{~d}(\mathrm{n}=46)$, respectively. Twentysix food samples were collected after trips of known duration: 12 after ST and 14 after LT (from 4 to $>10 \mathrm{~d}$ ). All the LT samples contained stomach oil (from traces to $4 \mathrm{ml}$ ) with generally an orange colour (sometimes yellowish), while only $1 \mathrm{ST}$ sample was oily $(1 \mathrm{ml})$, with the oil being an unusual brown colour.

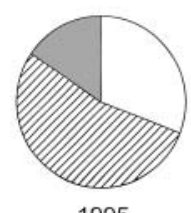

1995
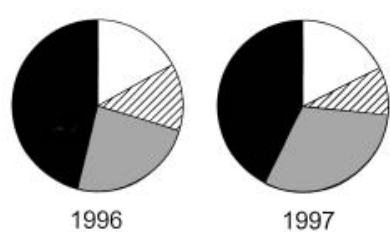

1997

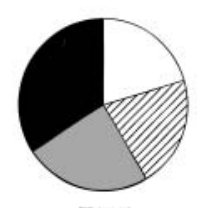

Total

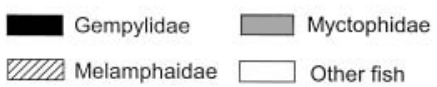

Fig. 6. Halobaena caerula. Composition by reconstituted mass of the fish diet during 3 consecutive chick-rearing periods

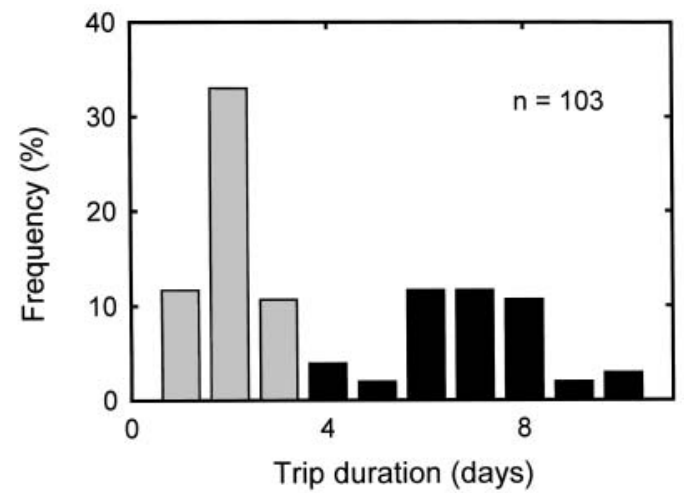

Fig. 7. Halobaena caerulea. Frequency distribution of the duration of adult foraging trips during chick-rearing in January 1998

In 1998 , as in the previous years, the diet was dominated by crustaceans $(98 \%$ of the total number of prey). The 2 main prey were, again, Thysanoessa sp. and Themisto gaudichaudii, but, compared with the other years, Thysanoessa sp. was much more abundant than T. gaudichaudii in 1998 (74 vs $11 \%$ by number). Thysanoessa sp. occurred more frequently (79 vs $33 \%$; Pearson $\chi^{2}=5.42, \mathrm{p}=0.020$ ) and was more numerous (86 vs $35 \%$; $\chi^{2}=1382, p<0.0001$ ) in LT than in ST samples, and the reverse was true for $T$. gaudichaudii (frequency of occurrence: 50 vs $92 \%$; $\chi^{2}=5.27, \mathrm{p}=0.022$; percentage by number: 1 vs $39 \% ; \chi^{2}=1589, \mathrm{p}<$ 0.0001). Blue petrels also fed more on Cyllopus magellanicus and Vibilia antarctica during ST $\left(\chi^{2}=49\right.$ and 151 , respectively; $\mathrm{p}<0.0001)$. Two of the prey occurred exclusively in one kind of foraging trip. The subantarctic krill Euphausia vallentini was found only in ST samples (frequency of occurrence: $42 \%$ ), and the Antarctic krill Euphausia superba in LT samples (71\%) (Table 4). Two stomach contents were collected after a $4 \mathrm{~d}$ trip; both contained orange-coloured oil, and E. superba occurred in 1 sample, thus indicating that $4 \mathrm{~d}$ trips were LT.

Since Euphausia superba indicates LT and stomach oil is much more prominent after LT than ST in the 1998 samples, food samples previously collected during the IOZ programme were divided into 2 groups according to the presence (presumably LT) or absence (presumably ST) of oil or E. superba. The comparison indicates that blue petrels fed more on the amphipods Polycheria kergueleni, Cyllopus magellanicus, Vibilia antarctica and Themisto gaudichaudii and the salp Salpa thompsoni during ST, and more on Thysanoessa sp., the shrimp Pasiphaea scotiae and gammarids of the genus Eurythenes during LT. Noticeably, the amphipods Cyphocaris richardi and Cyllopus lucasii were present during LT only. There was also a tendency for birds to prey more on fish, including myctophids, during LT. 
Table 4. Halobaena caerulea. Frequency of occurrence and number of prey items recovered in stomach contents collected from adults after short $(\mathrm{ST} ; \mathrm{n}=12)$ and long trips $\left(\mathrm{LT}_{;} \mathrm{n}=14\right)$ during chick-rearing in 1998

\begin{tabular}{|c|c|c|c|c|c|c|c|c|}
\hline \multirow[t]{3}{*}{ Prey species } & \multicolumn{4}{|c|}{ Occurrence in stomachs } & \multicolumn{4}{|c|}{ Number } \\
\hline & \multicolumn{2}{|c|}{ ST } & \multicolumn{2}{|c|}{$\mathrm{LT}$} & \multicolumn{2}{|c|}{ ST } & \multicolumn{2}{|c|}{$\mathrm{LT}$} \\
\hline & $\mathrm{n}$ & $\%$ & $\mathrm{n}$ & $\%$ & $\mathrm{n}$ & $\%$ & $\mathrm{n}$ & $\%$ \\
\hline Crustaceans & 12 & 100.0 & 14 & 100.0 & 1330 & 97.6 & 4212 & 98.3 \\
\hline \multicolumn{9}{|l|}{ Euphausiacea } \\
\hline Euphausia superba & 0 & 0.0 & 10 & 71.4 & 0 & 0.0 & 50 & 1.2 \\
\hline Euphausia vallentini & 5 & 41.7 & 0 & 0.0 & 77 & 5.7 & 0 & 0 \\
\hline Euphausia sp. & 1 & 8.3 & 2 & 14.3 & 2 & 0.1 & 33 & 0.8 \\
\hline Thysanoessa macrura/vicina & 4 & 33.3 & 11 & 78.6 & 474 & 34.8 & 3677 & 85.8 \\
\hline \multicolumn{9}{|l|}{ Decapoda } \\
\hline Pasiphae scotiae & 4 & 33.3 & 5 & 35.7 & 4 & 0.3 & 6 & 0.1 \\
\hline \multicolumn{9}{|l|}{ Amphipoda } \\
\hline Eurythenes gryllus/obesus & 2 & 16.7 & 5 & 35.7 & 2 & 0.1 & 5 & 0.1 \\
\hline Uristes gigas & 1 & 8.3 & 1 & 7.1 & 2 & 0.1 & 2 & $<0.1$ \\
\hline Cyllopus magellanicus & 10 & 83.3 & 10 & 71.4 & 113 & 8.3 & 156 & 3.6 \\
\hline Vibilia antarctica & 11 & 91.7 & 4 & 28.6 & 102 & 7.5 & 53 & 1.2 \\
\hline Hyperiella antarctica & 5 & 41.7 & 4 & 28.6 & 12 & 0.9 & 168 & 3.9 \\
\hline Hyperoche luetkenides & 2 & 16.7 & 1 & 7.1 & 2 & 0.1 & 1 & $<0.1$ \\
\hline Themisto gaudichaudii & 11 & 91.7 & 7 & 50.0 & 537 & 39.4 & 58 & 1.4 \\
\hline Unidentified crustaceans & 2 & 16.7 & 3 & 21.4 & 3 & 0.2 & 3 & $<0.1$ \\
\hline Fish & 7 & 58.3 & 8 & 57.1 & 16 & 1.2 & 13 & 0.3 \\
\hline \multicolumn{9}{|l|}{ Myctophidae } \\
\hline Electrona antarctica & 3 & 25.0 & 0 & 0.0 & 3 & 0.2 & 0 & 0 \\
\hline Electrona carlsbergi & 3 & 25.0 & 1 & 7.1 & 3 & 0.2 & 1 & $<0.1$ \\
\hline Gymnoscopelus microlampas & 1 & 8.3 & 0 & 0.0 & 1 & $<0.1$ & 0 & 0 \\
\hline Krefftichthys anderssoni & 0 & 0.0 & 2 & 14.3 & 0 & 0.0 & 3 & $<0.1$ \\
\hline Protomyctophum bolini & 0 & 0.0 & 1 & 7.1 & 0 & 0.0 & 1 & $<0.1$ \\
\hline Protomyctophum choriodon & 0 & 0.0 & 1 & 7.1 & 0 & 0.0 & 1 & $<0.1$ \\
\hline Unidentified Myctophidae & 5 & 41.7 & 2 & 14.3 & 5 & 0.4 & 2 & $<0.1$ \\
\hline \multicolumn{9}{|l|}{ Melamphaidae } \\
\hline Sio nordenskjöldii & 1 & 8.3 & 1 & 7.1 & 1 & $<0.1$ & 1 & $<0.1$ \\
\hline \multicolumn{9}{|l|}{ Nototheniidae } \\
\hline Gobionotothen acuta & 0 & 0.0 & 1 & 7.1 & 0 & 0.0 & 1 & $<0.1$ \\
\hline Unidentified fish & 2 & 16.7 & 2 & 14.3 & 3 & 0.2 & 3 & $<0.1$ \\
\hline Cephalopods & 6 & 50.0 & 2 & 14.3 & 7 & 0.5 & 2 & $<0.1$ \\
\hline \multicolumn{9}{|l|}{ Onychoteuthidae } \\
\hline Unidentified Onychoteuthidae & 0 & 0.0 & 1 & 7.1 & 0 & 0.0 & 1 & $<0.1$ \\
\hline Oegopsida sp. A & 4 & 33.3 & 1 & 7.1 & 5 & 0.4 & 1 & $<0.1$ \\
\hline Unidentified squids & 2 & 16.7 & 0 & 0.0 & 2 & 0.1 & 0 & 0 \\
\hline Others & 5 & 41.7 & 4 & 28.6 & 9 & 0.7 & 57 & 1.3 \\
\hline \multicolumn{9}{|l|}{ Polychaeta } \\
\hline Platynereis australis & 0 & 0.0 & 1 & 7.1 & 0 & 0.0 & 50 & 1.2 \\
\hline \multicolumn{9}{|l|}{ Salpidae } \\
\hline Salpa thompsoni & 4 & 33.3 & 2 & 14.3 & 8 & 0.6 & 2 & $<0.1$ \\
\hline Unidentified organism & 1 & 8.3 & 1 & 7.1 & 1 & $<0.1$ & 5 & 0.1 \\
\hline Total & 12 & & 14 & & 1362 & 100.0 & 4284 & 100 \\
\hline
\end{tabular}

\section{Stable isotopes}

A brief examination showed the occurrence of crustaceans in all 9 food samples and of fish (mainly myctophids) in 6 samples. Food of blue petrels and feathers from chicks and adults were segregated by their stable isotope values (multivariate analysis of variance, Wilk's lambda, $F_{4,50}=18.07, \mathrm{p}<0.0001$ ) (Table 5). Both $\delta^{13} \mathrm{C}$ and $\delta^{15} \mathrm{~N}$ values were different overall. The carbon stable isotope ratio of chick feathers was higher than the ratio in adult feathers (post hoc Tukey's HSD multiple comparison test: $\mathrm{p}=0.027$ ), and nitrogen stable 
Table 5. Halobaena caerulea. Stable carbon and nitrogen isotope concentrations (mean $\pm \mathrm{SD} \%$ ) in dietary samples and in feathers of breeding adults and chicks at Iles Kerguelen, and results of 1-way ANOVA for differences among groups for each isotope. Values in the same column not sharing a common superscript letter are significantly different (post hoc Tukey HSD multiple comparison test, $\mathrm{p}<0.05$ )

\begin{tabular}{|lrcr|}
\hline Sampling group & $\mathrm{n}$ & $\delta^{13} \mathrm{C}$ & \multicolumn{1}{c|}{$\delta^{15} \mathrm{~N}$} \\
\hline Food & 9 & $-23.7 \pm 2.5^{\mathrm{a}, \mathrm{b}}$ & $5.5 \pm 1.5^{\mathrm{a}}$ \\
Chick feathers & 10 & $-22.2 \pm 0.6^{\mathrm{a}}$ & $9.7 \pm 0.8^{\mathrm{b}}$ \\
Adult feathers & 10 & $-24.2 \pm 1.3^{\mathrm{b}}$ & $9.1 \pm 0.6^{\mathrm{b}}$ \\
ANOVA & & $F_{2,26}=4.18$ & $F_{2,26}=47.79$ \\
& & $\mathrm{p}=0.027$ & $\mathrm{p}<0.0001$ \\
\hline
\end{tabular}

isotope ratio of chick food was lower than the ratios in chick and adult feathers (all p < 0.0001) (Table 5).

\section{Breeding success}

Hatching and fledging successes of blue petrels averaged 55 and $79 \%$, respectively, and they did not vary significantly between the 3 study years (hatching success: $\chi^{2}{ }_{2}=0.99, p=0.610$; fledging success: $\chi^{2}{ }_{2}=0.49, p$ $=0.781$ ). Consequently, breeding success averaged $43 \%$, with no inter-annual variations (Table 6). However, chick body masses measured at the same date each year were different during the 3 fledging periods (post hoc Tukey's HSD multiple comparison test, all p < 0.001). Wing length were also overall different, being larger in 1997 than in 1995 (post hoc Tukey's HSD multiple comparison test, $\mathrm{p}=0.001$ ) (Table 6).

\section{DISCUSSION}

At Iles Kerguelen, blue petrels rearing chicks prey mainly on mesopelagic fish and 2 crustacean items, the hyperiid amphipod Themisto gaudichaudii and the euphausiid Thysanoessa sp. Birds feed more on T. gaudichaudii during ST and more on Thysanoessa sp. during LT. The occurrence of Euphausia vallentini and E. superba in ST and LT samples, respectively, indicates foraging in subantarctic waters during ST and in distant southern Antarctic waters during LT. The stable carbon and nitrogen isotopic compositions of chick and adult feathers suggest that adult birds renew their flight feathers in Antarctic waters, and that they feed at the same trophic level during the chick-rearing and moulting periods.

No inter-annual variations in chick-feeding frequency and in food mass were observed during the 3 years of the IOZ programme. Chicks' growth differed between years, but hatching, fledging and breeding successes were identical between the 3 reproductive seasons. When comparing with breeding success over a longer period (1986/87 to 1994/95, range 26 to $62 \%$ ), 1994/95, 1995/96 and 1996/97 were normal years (42 to $46 \%$ ), but $1997 / 98$ was a bad breeding season (28\%), as previously observed in 1987/88 (28\%) and 1991/92 (26\%) (Guinet et al. 1998). The Kerguelen region was marked by a short-term climatic change in the late 1990s, as indicated by an abrupt increase in sea level, which peaked at the end of 1997 to the beginning of 1998, a period coinciding with the strongest El Niño southern oscillation of the last century (Park 2001). Such dramatic changes probably affected the pelagic ecosystem surrounding the archipelago and probably explain the unusual high and low importance of Thysanoessa sp. (74\% by number) and Themisto gaudichaudii $(11 \%)$, respectively, in the diet of blue petrels in 1998 .

Table 6. Halobaena caerulea. Breeding success and fledging mass during 3 consecutive breeding seasons. Values are means \pm SD with ranges in parentheses

\begin{tabular}{|c|c|c|c|c|c|c|c|c|c|}
\hline $\begin{array}{l}\text { Study } \\
\text { period }\end{array}$ & $\begin{array}{l}\text { Monitored } \\
\text { burrows } \\
\text { (n) }\end{array}$ & $\begin{array}{c}\text { Occupied } \\
\text { burrows } \\
\text { (n) }\end{array}$ & $\begin{array}{c}\text { Occupied } \\
\text { burrows } \\
(\%)\end{array}$ & $\begin{array}{l}\text { Hatching } \\
\text { success } \\
(\%)\end{array}$ & $\begin{array}{c}\text { Fledging } \\
\text { success } \\
(\%)\end{array}$ & $\begin{array}{l}\text { Breeding } \\
\text { success } \\
(\%)\end{array}$ & $\begin{array}{l}\text { Chicks' } \\
\text { body mass } \\
\text { (g) }\end{array}$ & $\begin{array}{c}\text { Chicks' } \\
\text { wing length } \\
(\mathrm{mm})\end{array}$ & $\begin{array}{l}\text { Number } \\
\text { of chicks }\end{array}$ \\
\hline 1995 & 231 & 141 & 61.0 & 51.5 & 81.1 & 41.7 & $156 \pm 30 \quad(92-212)$ & $138 \pm 21 \quad(76-172)$ & 43 \\
\hline 1996 & 233 & 138 & 59.2 & 57.4 & 80.6 & 46.2 & $216 \pm 39(146-327)$ & $144 \pm 24 \quad(97-180)$ & 25 \\
\hline 1997 & 207 & 160 & 77.9 & 58.9 & 75.8 & 44.6 & $186 \pm 30(118-236)$ & $154 \pm 20(109-199)$ & 50 \\
\hline \multirow[t]{2}{*}{ Total } & 671 & 439 & 65.4 & 55.3 & 78.7 & 43.5 & $182 \pm 39 \quad(92-327)$ & $146 \pm 22 \quad(76-199)$ & 118 \\
\hline & & & & & & $\begin{array}{l}\chi^{2}{ }_{2}=0.34 \\
\mathrm{p}=0.842^{\mathrm{a}}\end{array}$ & $\begin{array}{l}F_{2,115}=28.08 \\
\mathrm{p}<0.0001^{\mathrm{a}}\end{array}$ & $\begin{array}{l}F_{2,115}=7.31 \\
\mathrm{p}=0.001^{\mathrm{a}}\end{array}$ & \\
\hline
\end{tabular}


majority of fish (71\%) were identified to species level, thus allowing the first precise qualitative and quantitative assessment of the fish diet of blue petrels. The amazing diversity of prey items includes a lot of fish that are known to live primarily in the mesopelagic, including myctophids and melamphaids, together with the gempylid Paradiplospinus gracilis (Gon \& Heemstra 1990). All the determined myctophid species, except Gymnoscopelus microlampas, are abundant in the polar frontal zone and in Antarctic waters (Hulley 1981, 1990, Duhamel 1998). The few fish specimens identified in the food of blue petrels nesting at Marion Island (Steele \& Klages 1986) and Iles Crozet (Ridoux 1994) belonged mostly to that family, as did the main prey of birds collected at sea in Antarctic waters (Ainley et al. 1992). Myctophids were also previously supposed to be major items of blue petrels at South Georgia (Prince 1980). The data thus emphasise the importance of these small shoaling oceanic fish in the nutrition of seabirds from the Southern Ocean (Ainley et al. 1992, Sabourenkov 1992, Guinet et al. 1996). On the other hand, the present work is, to our knowledge, the first to describe melamphaids and $P$. gracilis as important items for an avian predator. Melamphaids are rare meso- and bathypelagic fish (Gon 1990), and they were accordingly found very occasionally in the diet of seabirds, including the blue petrel (Cherel \& Klages 1998, Ridoux 1994, Lorentsen et al. 1998, Catard et al. 2000). Little is known about the biology of $P$. gracilis, but the species lives mainly in the vicinity of land masses, including Iles Kerguelen (Nakamura 1990, Duhamel 1998). It was previously identified as a significant prey of penguins in a few studies (Klages et al. 1990, Cherel \& Ridoux 1992) and only as a minor item in the diet of procellariiforms (Ridoux 1994, Cherel \& Klages 1998). How these deep-sea fish become available to surface-feeding seabirds remains, however, to be determined, as does their time of capture (daytime versus nighttime) and the extent of their daily vertical migration in the water column.

At Iles Kerguelen, which is near the Antarctic polar front (Park et al. 1993), the 2 main crustacean prey of blue petrels are Themisto gaudichaudii and Thysanoessa sp. Further north, at Crozet and Marion islands, they feed on the same 2 species plus the subantarctic krill Euphausia vallentini and further south, at South Georgia, on the Antarctic krill Euphausia superba (Table 7). Taken together, these data suggest that the blue petrel is an opportunist feeder that preys on the most available swarming pelagic crustaceans found in its foraging grounds during the breeding season. $T$. gaudichaudii is one of the main macrozooplankton species in the Southern Ocean (Kane 1966), including the Iles Kerguelen (Bocher et al. 2001). There, blue petrels consistently caught 2 size classes of the amphi- pod, with large inter-annual variations in their relative importance (Fig. 3). The size structure of T. gaudichaudii in food samples was different from that observed in the vicinity of the breeding colony (Bocher et al. 2001), indicating that amphipods were caught in more offshore waters. This is also supported by the abundance of Thysanoessa sp. in the blue petrel diet because this euphausiid does not occur in the Golfe du Morbihan (Bost et al. 1994, Bocher et al. 2001). Two species of the genus Thysanoessa, $T$. vicina and $T$. macrura, live in the vicinity of the Antarctic polar front and in Antarctic waters, including the Kerguelen region (Lomakina 1966, Pakhomov 1993). The digested condition of the specimens in food samples precluded their identification to the species level, but the occurrence of 1 well-defined size class suggests they belonged to 1 species only (Fig. 4).

The occurrence in significant numbers of Polycheria kergueleni in the diet of blue petrels is surprising because this gammarid amphipod is primarily benthic. It occurs commonly at the bottom in coastal waters of Iles Kerguelen (Arnaud 1974, Bellan-Santini \& Ledoyer 1974) and is also found associated with the giant kelp Macrocystis pyrifera (Arnaud 1974). This, together with observations of blue petrels feeding in inshore waters (Falla 1937), shows that some blue petrels forage close to the coastline in the kelp belt area surrounding the archipelago, probably when they commute between colonies and offshore feeding grounds. On the other hand, the occurrence in food samples of the gammarids Cyphocaris richardi, Eurythenes spp. and Parandania boecki indicate feeding in more distant areas, because these species are strictly pelagic or benthopelagic organisms living in oceanic waters (Barnard 1961, Vinogradov 1999). During the chick-rearing period, blue petrels thus forage in a wide variety of habitats where they feed on different marine organisms.

Isotopic signatures of chick feathers of blue petrels show an enrichment relative to food amounting to $1.5 \%$ or $\delta^{13} \mathrm{C}$ and $4.2 \%$ for $\delta^{15} \mathrm{~N}$ (Table 5). These values are within the range of those $\left(-0.4\right.$ to $4.4 \%$ for $\delta^{13} \mathrm{C}$ and 1.1 to $5.6 \%$ for $\delta^{15} \mathrm{~N}$ ) obtained from feathers of various species of birds (Mizutani et al. 1990, 1992, Hobson \& Clark 1992a,b, Thompson \& Furness 1995), including procellariiforms from Iles Kerguelen (Bocher et al. 2000, Cherel et al. 2000a, 2002). Stable nitrogen isotope ratios are similar in chick and adult feathers of blue petrels, indicating that during moult adults fed at the same trophic level as during the breeding period. $\delta^{13} \mathrm{C}$ values of adult feathers, however, differ from those in chick feathers. Taking into account latitudinal variations in $\delta^{13} \mathrm{C}$ (François et al. 1993), the low value of adult feathers suggests birds moulted in southern Antarctic waters, an hypothesis reinforced by the fact 
Table 7. Halobaena caerulea. Broad prey classes and proportions by number $(\% \mathrm{~N})$ and by reconstituted mass $(\% \mathrm{M})$ of the main prey species $(\geq 10 \%)$ in the diet of blue petrels breeding at different localities

\begin{tabular}{|c|c|c|c|c|c|c|c|c|}
\hline & \multicolumn{2}{|c|}{$\begin{array}{l}\text { Marion } \\
\text { (Steele \& Klages 1986) } \\
(\mathrm{n}=49)\end{array}$} & \multicolumn{2}{|c|}{$\begin{array}{c}\text { Crozet } \\
\text { (Ridoux 1994) } \\
(\mathrm{n}=33)\end{array}$} & \multicolumn{2}{|c|}{$\begin{array}{l}\text { Kerguelen } \\
\text { (Present study) } \\
(\mathrm{n}=105)\end{array}$} & \multicolumn{2}{|c|}{$\begin{array}{l}\text { South Georgia } \\
\text { (Prince 1980) } \\
(\mathrm{n}=156)\end{array}$} \\
\hline & $\% \mathrm{~N}$ & $\% \mathrm{M}$ & $\% \mathrm{~N}$ & $\% \mathrm{M}$ & $\% \mathrm{~N}$ & $\% \mathrm{M}$ & $\% \mathrm{~N}$ & $\% \mathrm{M}$ \\
\hline Crustaceans & 92 & 59 & 99 & 61 & 98 & 37 & 94 & 91 \\
\hline Euphausia superba & - & - & $<1$ & 4 & 2 & 10 & $24^{\mathrm{a}}$ & $82^{\mathrm{a}}$ \\
\hline Euphausia vallentini & 64 & 34 & 13 & 14 & 2 & $<1$ & - & - \\
\hline Thysanoessa sp. & - & - & 28 & 14 & 42 & 4 & $29^{\mathrm{a}}$ & $4^{\mathrm{a}}$ \\
\hline Hyperoche sp. & - & - & $<1$ & $<1$ & $<1$ & $<1$ & $11^{\mathrm{a}}$ & $2^{\mathrm{a}}$ \\
\hline Themisto gaudichaudii & 4 & 3 & 50 & 12 & 42 & 12 & $4^{\mathrm{a}}$ & $<1^{\mathrm{a}}$ \\
\hline $\begin{array}{l}\text { Rhincalanus gigas / } \\
\text { Calanoides acutus }\end{array}$ & - & - & $<1$ & $<1$ & $<1$ & $<1$ & $13^{\mathrm{a}}$ & $1^{\mathrm{a}}$ \\
\hline Fish & 3 & 21 & $<1$ & 11 & $<1$ & 57 & 6 & 8 \\
\hline Myctophidae & Present & Present & $<1$ & 5 & $<1$ & 14 & Present & Present \\
\hline Melamphaidae & - & - & - & - & $<1$ & 12 & - & - \\
\hline Paradiplospinus gracilis & - & - & $<1$ & 1 & $<1$ & 19 & - & - \\
\hline Cephalopods & 2 & 16 & $<1$ & 27 & $<1$ & 2 & $<1$ & $<1$ \\
\hline Others & 3 & 4 & $<1$ & 2 & $<1$ & 4 & - & - \\
\hline
\end{tabular}

that truly Antarctic animals, including fulmarine petrels, have similar low $\delta^{13} \mathrm{C}$ values (Hodum \& Hobson 2000). Accordingly, observations at sea of moulting blue petrels were confined to south of Iles Kerguelen, in Antarctic waters between $60^{\circ} \mathrm{S}$ and Prydz Bay (Stahl et al. in press).

\section{ST, LT and foraging areas}

As previously described (Chaurand \& Weimerskirch 1994), adult blue petrels foraged on ST and LT to feed their chicks in January 1998 (Fig. 7). The main interannual difference was that no trips of $4 \mathrm{~d}$ were recorded in January 1989 (Chaurand \& Weimerskirch 1994). In 1998, the 4 d trips are clearly LT, as indicated by the presence of stomach oil and of Euphausia superba in food samples. Data from the 2 years thus show that blue petrels consistently make ST with a mode at $2 \mathrm{~d}$ and LT with a mode at 6 to $8 \mathrm{~d}$ during the chickrearing period at Kerguelen. This 2-fold strategy, first described in the blue petrel, has now been generalised to many procellariiform seabirds, including albatrosses, prions, shearwaters and petrels (Weimerskirch et al. 1994, 2001, Granadeiro et al. 1998). Satellite tracking of the largest species show that birds forage in different areas during ST and LT (Weimerskirch et al. 1997, Catard et al. 2000, Waugh et al. 2000). Smaller size, however, precludes the use of electronic devices, but biogeography of the prey identified in food samples has the potential to give a first insight into the foraging grounds during ST and LT (Weimerskirch \& Cherel 1998, Weimerskirch et al. 1999).

After LT, but not ST, food samples of blue petrels consistently contained stomach oil, as recently found in short-tailed shearwaters Puffinus tenuirostris and Antarctic prions Pachyptila desolata (Weimerskirch \& Cherel 1998, Weimerskirch et al. 1999). This is in agreement with the idea that the primarily function of stomach oil is to act as a rich energy reserve by concentrating lipids from the prey, being thus an easy and cheap way to bring and transport energy to the chicks from distant foraging areas (Warham 1977). Together with stomach oil, the best indicator of LT was the Antarctic krill Euphausia superba because it was found in LT samples only (Table 4). Blue petrels feed on both juvenile and adult Antarctic krill with large inter-annual differences, as indicated by their lengthfrequency distribution (Fig. 5). Since the northern limit of E. superba south of Iles Kerguelen is $59^{\circ} \mathrm{S}$, with the highest densities always recorded further south (Hosie et al. 1988, Miquel 1991, Pakhomov 2000), its occurrence in food samples indicate foraging far away, in southern Antarctic waters located more than $1000 \mathrm{~km}$ from the breeding grounds $\left(49^{\circ} \mathrm{S}\right)$ (Fig. 1). Observations at sea are in agreement with our data because foraging and feeding blue petrels were recorded in summer over Antarctic waters between 62 and $64^{\circ} \mathrm{S}$ south of Iles Kerguelen, and in Prydz Bay (Ryan \& Cooper 1989, Stahl et al. in press). In the latter area, blue petrels are among the commonest seabirds recorded north of the Antarctic divergence (64을 
the species was found to be positively correlated with the abundance of E. superba (Ryan \& Cooper 1989). Feeding in southern Antarctic waters is also indicated by the occurrence of Cyllopus lucasii in a few food samples (Table 3) because the 2 Cyllopus species have different patterns of distribution, C. lucasii being much more frequent to the south, C. magellanicus to the north (Weigmann-Haass 1983).

The presence of Euphausia superba in the diet at Crozet $\left(46^{\circ} \mathrm{S}\right.$ ) (Ridoux 1994) suggests that blue petrels also make LT at that breeding locality. The lack of $E$. superba in the food of blue petrels from Marion Island $\left(47^{\circ} \mathrm{S}\right)$ (Steele \& Klages 1986), which is also located in the Western Indian Ocean, is more puzzling and may result either from the inability to identify very digested remains of E. superba that can be easily overlooked in food samples or from a different foraging strategy. However, the occurrence of oil in $58 \%$ of the samples (Steele \& Klages 1986) clearly suggests that birds also use a 2 -fold strategy there. Antarctic krill is very abundant in the immediate vicinity of South Georgia $\left(55^{\circ} \mathrm{S}\right)$, and, consequently, it is the main food item of blue petrels (Prince 1980). Whether this leads to a different feeding strategy clearly merits further studies to investigate the foraging plasticity of the species in relation to the marine environment.

Unlike in January 1998, deep-water crustaceans (Eurythenes spp. and Pasiphaea longispina [= P. scotiae]) were found exclusively in LT samples in January 1989 (Chaurand \& Weimerskirch 1994). They were also clearly associated with oil or Euphausia superba, i.e. presumably LT samples, in stomach contents collected during the IOZ programme. Such differences may result from inter-annual variations because, as previously detailed above, the beginning of 1998 was marked by oceanographic anomalies (Park 2001) and thus probably changes in the pelagic ecosystem. During LT, blue petrels fed more on Thysanoessa macrura/ vicina than during $\mathrm{ST}$, and the reverse was true for Themisto gaudichaudii. The 2 taxons have a broad circumpolar distribution in the Southern Ocean (Kane 1966, Lomakina 1966), and they thus cannot give valuable information on foraging grounds. It is, however, noticeable that the density of T. gaudichaudii increases in the vicinity of Iles Kerguelen (Pakhomov 1993, Bocher et al. 2001). The subantarctic krill Euphausia vallentini was clearly associated with $\mathrm{ST}$, as were the amphipods Polycheria kergueleni, Cyllopus magellanicus and Vibilia antarctica and the salp Salpa thompsoni. P. kergueleni is associated with the kelp belt (see above), E. vallentini occurs in coastal, neritic and subantarctic oceanic waters (Pakhomov 1993, Bost et al. 1994), and C. magellanicus and V. antarctica are known to live in association with $S$. thompsoni (Perissinotto \& Pakhomov 1997), all being common in oceanic waters surrounding the archipelago (Pakhomov 1993, Cherel et al. unpubl.). Together with the occurrence of mesopelagic fish and deep-water crustaceans, the data suggest foraging mainly, but not exclusively, in oceanic waters during ST. Observations at sea indicate that blue petrels are common between Iles Kerguelen and Heard Island in January and February (Stahl et al. in press), the area being thus presumably one of the foraging grounds during ST. Being located south of Iles Kerguelen, it may also explain the occurrence of the same prey species in ST and LT samples, adult blue petrels collecting food for their chicks on their way back from the distant Antarctic foraging grounds to the colonies, as previously found for other procellariiforms (Weimerskirch \& Cherel 1998, Weimerskirch et al. 1999).

In summary, prey biogeography indicates foraging in the relative vicinity of Iles Kerguelen during ST and to southern Antarctic waters during LT, a conclusion that fits well with the time windows available for travelling and foraging during the 2 kinds of trips, i.e. about 2 and 6 to $8 \mathrm{~d}$ for ST and LT, respectively.

\section{Blue petrels and prions}

When closely related species are in sympatric conditions, some segregation in nest sites or food can be expected. At Iles Kerguelen, we studied during 3 consecutive breeding seasons the food and feeding ecology of 2 species of the genus Pachyptila, the thin-billed and Antarctic prions (Cherel et al. 2002), together with that of blue petrels (present study). An almost complete segregation was previously observed in the nesting habitats, together with a partial segregation in the timing of breeding, blue petrels being slightly in advance of thin-billed prions, and Antarctic prions reproducing $40 \mathrm{~d}$ later than their congenerics (Weimerskirch et al. 1989, Bretagnolle et al. 1990, Genevois \& Buffard 1994). Dietary analysis showed a broad overlap in the prey species and presumably the foraging areas of prions and blue petrels (Cherel et al. 2002, present study). Blue petrels, however, fed more on fish (mainly mesopelagic species) than prions (57 vs $12-13 \%$ by reconstituted mass), and, conversely, prions fed more on crustaceans (82 vs $37 \%$ ). During the only previous study comparing the diet of blue petrels and Antarctic prions, Prince (1980) also found that the 2 species are segregated by the amount of fish in their food. At Iles Kerguelen, the main crustacean prey was Themisto gaudichaudii for the 3 bird species, thus emphasising its importance in the local pelagic trophic web (Bocher et al. 2001). Birds segregated by feeding on different euphausiids: Thysanoessa sp. for blue petrels and thinbilled prions, and Euphausia vallentini for Antarctic 
prions. Interestingly, E. vallentini was also the main prey for blue petrels during the post-nuptial visit to their burrows, suggesting that this euphausiid species is more available for surface-feeding seabirds in March to May than earlier in the season.

The stable isotopic composition of chick feathers also indicated an overlap in the foraging ecology of the species during the chick-rearing period. $\delta^{13} \mathrm{C}$ was similar in feathers of the 3 groups of chicks, but, in agreement with more fish in its diet, $\delta^{15} \mathrm{~N}$ was higher for the blue petrel. Outside the breeding season, during moult, birds segregated by their foraging areas. Stable carbon isotope concentrations of adult feathers indicated that blue petrels and thin-billed prions renewed their flight feathers in Antarctica, and Antarctic prions in subtropical waters (Cherel et al. 2002, present study).

Like blue petrels, both thin-billed and Antarctic prions made ST and LT during the chick-rearing period at Iles Kerguelen (Weimerskirch et al. 1999, Duriez et al. 2000). ST are, however, shorter in prions (mode at $1 \mathrm{~d}$ ) than in blue petrels $(2 \mathrm{~d})$. Together with the higher occurrence of oceanic prey in blue petrel food samples, it is therefore suggested that prions forage more in neritic waters and blue petrels more in oceanic waters in the vicinity of the archipelago during ST. Another difference is that blue petrels alternate one ST with one LT (Chaurand \& Weimerskirch 1994, Weimerskirch et al. unpubl.), while prions alternate several successive ST with one LT (Weimerskirch et al. 1999, Duriez et al. 2000). Consequently, blue petrels make more LT than prions. This difference is the more likely explanation for the higher frequency of occurrence of Euphausia superba (35 vs $10-15 \%$ ) and its higher importance by reconstituted mass (10 vs $4 \%$ ) in the diet of blue petrels than in that of prions. Note, however, that the 3 species reach southern Antarctic waters during LT (Cherel et al. 2002, present study).

Ecologically, blue petrels and thin-billed and Antarctic prions belong to a group of small and mediumsized procellariiform seabirds that make LT to Antarctic waters during the chick-rearing period. In addition to these 3 species, this feeding strategy has been described for the white-chinned petrel Procellaria aequinoctialis (Catard et al. 2000) and the short-tailed shearwater (Weimerskirch \& Cherel 1998, Klomp \& Schultz 2000), and it is suspected to occur in the whiteheaded petrels Pterodroma lessoni and mottled petrels $P$. inexpectata, because the 2 species are numerous in Antarctic waters in January and February (Veit \& Hunt 1991). Adult petrels observed at high latitudes in summer are therefore not only non-breeders or failed breeders, as is generally assumed, but at least some are breeding birds that forage far from their breeding grounds to build up energy reserves and collect food for their chicks.
Acknowledgements. The authors thank K. A. Hobson for analysing stable isotopes and S. Razouls for her help in copepod determination. They also thank J. Bried, S. Caulle, O. Duriez, G. Fradet, F. Jiguet, G. Juin, B. Labidoire, T. Mougey and D. Secondi for their work in the field. Analysis of the data was supported financially by a grant from Conseils Généraux des Deux-Sèvres et de la Charente Maritime, and by a grant from the Groupement de Recherche en Environnement 1069 'Ecosystèmes Polaires et Anthropisation' (directed by Pierre Jouventin), from the CNRS (Programme IOZ: Interactions Oiseaux-Zooplancton). Field work was supported financially and logistically by the Institut Français pour la Recherche et la Technologie Polaires (IFRTP, Programme No. 109), and the Terres Australes et Antarctiques Françaises.

\section{LITERATURE CITED}

Adams NJ, Klages NT (1987) Seasonal variation in the diet of the king penguin (Aptenodytes patagonicus) at subAntarctic Marion Island. J Zool 212:303-324

Ainley DG, Ribic CA, Fraser WR (1992) Does prey preference affect habitat choice in Antarctic seabirds? Mar Ecol Prog Ser 90:207-221

Arnaud PM (1974) Contribution à la bionomie marine benthique des régions antarctiques et subantarctiques. Tethys 6:465-656

Baker A de C, Boden BP, Brinton E (1990) A practical guide to the euphausiids of the world. Natural History Museum Publications, London

Barnard JL (1961) Gammaridean Amphipoda from depths of 400 to 6000 meters. Galathea Rep 5:23-128

Bellan-Santini D, Ledoyer M (1974) Gammariens (CrustaceaAmphipoda) des Iles Kerguelen et Crozet. Tethys 5: 635-708

Bocher P, Cherel Y, Hobson KA (2000) Complete trophic segregation between South Georgian and common diving petrels during breeding at Iles Kerguelen. Mar Ecol Prog Ser 208:249-264

Bocher P, Cherel Y, Labat JP, Mayzaud P, Razouls S, Jouventin P (2001) Amphipod-based food web: Themisto gaudichaudii caught in nets and by seabirds in Kerguelen waters, Southern Indian Ocean. Mar Ecol Prog Ser 223: 261-276

Boltovskoy D (1999) South Atlantic zooplankton. Backhuys Publishers, Leiden

Bost CA, Koubbi P, Genevois F, Ruchon L, Ridoux V (1994) Gentoo penguin Pygoscelis papua diet as an indicator of planktonic availability. Polar Biol 14:147-153

Bretagnolle V, Zotier R, Jouventin P (1990) Comparative population biology of four prions (Genus Pachyptila) from the Indian Ocean and consequences for their taxonomic status. Auk 107:305-316

Catard A, Weimerskirch H, Cherel Y (2000) Exploitation of distant Antarctic waters and close shelf-break waters by white-chinned petrels rearing chicks. Mar Ecol Prog Ser 194:249-261

Chaurand T, Weimerskirch H (1994) The regular alternation of short and long foraging trips in the blue petrel Halobaena caerulea: a previously undescribed strategy of food provisioning in a pelagic seabird. J Anim Ecol 63: $275-282$

Cherel Y, Klages N (1998) A review of the food of albatrosses. In: Robertson G, Gales R (eds) Albatross biology and conservation. Surrey Beatty \& Sons, Chipping Norton, p 113-136 
Cherel Y, Ridoux V (1992) Prey species and nutritive value of food fed during summer to king penguin Aptenodytes patagonica chicks at Possession Island, Crozet Archipelago. Ibis 134:118-127

Cherel Y, Hobson KA, Weimerskirch H (2000a) Using stableisotope analysis of feathers to distinguish moulting and breeding origins of seabirds. Oecologia 122:155-162

Cherel Y, Weimerskirch H, Trouvé C (2000b) Food and feeding ecology of the neritic-slope forager black-browed albatross and its relationships with commercial fisheries in Kerguelen waters. Mar Ecol Prog Ser 207:183-199

Cherel Y, Bocher P, De Broyer C, Hobson KA (2002) Food and feeding ecology of the sympatric thin-billed Pachyptila belcheri and Antarctic P. desolata prions at Iles Kerguelen. Mar Ecol Prog Ser 228:263-281

Clarke A, Holmes LJ (1987) Notes on the biology and distribution of Pasiphaea species from the Southern Ocean. Br Antarct Surv Bull 74:17-30

Duhamel G (1998) The pelagic fish community of the Polar Frontal Zone off the Kerguelen Islands. In: di Prisco G, Pisano E, Clarke A (eds) Fishes of Antarctica, a biological overview. Springer Verlag, Berlin, p 63-74

Duriez O, Weimerskirch H, Fritz H (2000) Regulation of chick provisioning in the thin-billed prion: an interannual comparison and manipulation of parents. Can J Zool 78: 1275-1283

Falla RA (1937) Birds. Rep B A N Z Antarct Res Exp 1929-31 2B:1-304

François R, Altabet MA, Goericke R, McCorkle DC, Brunet C, Poisson A (1993) Changes in the $\delta^{13} \mathrm{C}$ of surface water particulate organic matter across the Subtropical Convergence in the SW Indian Ocean. Global Biogeochem Cycles $7: 627-644$

Fugler SR, Hunter S, Newton IP, Steele WK (1987) Breeding biology of blue petrels Halobaena caerulea at the Prince Edward Islands. Emu 87:103-110

Genevois F, Buffard E (1994) Sites de nidification et caractéristiques des terriers chez deux espèces de pétrels sympatriques aux Iles Kerguelen: le pétrel bleu Halobaena caerulea et le prion de Belcher Pachyptila belcheri. Alauda 62:123-134

Gon O (1990) Family Melamphaidae. In: Gon O, Heemstra PC (eds) Fishes of the Southern Ocean. JLB Smith Institute of Ichthyology, Grahamstown, p 218-221

Gon O, Heemstra PC (eds) (1990) Fishes of the Southern Ocean. JLB Smith Institute of Ichthyology, Grahamstown

Granadeiro JP, Nunes M, Silva MC, Furness RW (1998) Flexible foraging strategy of Cory's shearwater, Calonectris diomedea, during the chick-rearing period. Anim Behav 56:1169-1176

Guinet C, Cherel Y, Ridoux V, Jouventin P (1996) Consumption of marine resources by seabirds and seals in Crozet and Kerguelen waters: changes in relation to consumer biomass 1962-85. Antarct Sci 8:23-30

Guinet C, Chastel O, Koudil M, Durbec JP, Jouventin P (1998) Effects of warm sea-surface temperature anomalies on the blue petrel at the Kerguelen Islands. Proc R Soc Lond B Biol Sci 265:1001-1006

Hindell MA (1988) The diet of the king penguin Aptenodytes patagonicus at Macquarie Island. Ibis 130:193-203

Hobson KA, Clark RG (1992a) Assessing avian diets using stable isotopes I: turnover of ${ }^{13} \mathrm{C}$ in tissues. Condor 94:181-188

Hobson KA, Clark RG (1992b) Assessing avian diets using stable isotopes II: factors influencing diet-tissue fractionation. Condor 94:189-197

Hodum PJ, Hobson KA (2000) Trophic relationships among Antarctic fulmarine petrels: insights into dietary overlap and chick provisioning strategies inferred from stableisotope $\left(\delta^{15} \mathrm{~N}\right.$ and $\left.\delta^{13} \mathrm{C}\right)$ analyses. Mar Ecol Prog Ser 198: $273-281$

Hosie GW, Ikeda T, Stolp M (1988) Distribution, abundance and population structure of the Antarctic krill (Euphausia superba Dana) in the Prydz Bay Region, Antarctica. Polar Biol 8:213-224

Hulley PA (1981) Results of the research cruises of FRV 'Walther Herwig' to South America. LVIII. Family Myctophidae (Osteichthyes, Myctophiformes). Arch Fisch Wiss 31:1-300

Hulley PA (1990) Family Myctophidae. In: Gon O, Heemstra PC (eds) Fishes of the Southern Ocean. JLB Smith Institute of Ichthyology, Grahamstown, p 146-178

Huntley ME, Sykes PF, Marin V (1989) Biometry and trophodynamics of Salpa thompsoni foxton (Tunicata: Thaliacea) near the Antarctic Peninsula in austral summer, 1983-1984. Polar Biol 10:59-70

Kane JE (1966) The distribution of Parathemisto gaudichaudii (Guér.), with observations on its life-history in the $0^{\circ}$ to $20^{\circ} \mathrm{E}$ sector of the Southern Ocean. Disc Rep 34:163-198

Kelly JF, Finch DM (1998) Tracking migrant songbirds with stable isotopes. Trends Ecol Evol 13:48-49

Klages NTW, Cooper J (1992) Bill morphology and diet of a filter-feeding seabird: the broad-billed prion Pachyptila vittata at South Atlantic Gough Island. J Zool 227:385-396

Klages NTW, Pemberton D, Gales RP (1990) The diets of king and gentoo penguins at Heard Island. Aust Wildl Res 17: $53-60$

Klomp NI, Schultz MA (2000) Short-tailed shearwaters breeding in Australia forage in Antarctic waters. Mar Ecol Prog Ser 194:307-310

Lomakina NB (1966) The Euphausiid fauna of the Antarctic and notal regions. In: Andriashev AP, Ushakov PV (eds) Biological reports of the Soviet Antarctic Expedition 1955-58, Vol 2. Israel Programme for Scientific Translations, Jerusalem, p 260-342

Lorentsen SH, Klages N, Røv N (1998) Diet and prey consumption of Antarctic petrels Thalassoica antarctica at Svarthamaren, Dronning Maud Land, and at sea outside the colony. Polar Biol 19:414-420

Marchant S, Higgins PJ (1990) Handbook of Australian, New Zealand and Antarctic birds, Vol 1. Oxford University Press, Melbourne

Miquel JC (1991) Distribution and abundance of post-larval krill (Euphausia superba Dana) near Prydz Bay in summer with reference to environmental conditions. Antarct Sci 3: 279-292

Mizdalski E (1988) Weight and length data of zooplankton in the Weddell Sea in austral spring 1986 (ANT V/3). Ber Polarforsch 55:1-72

Mizutani H, Fukuda M, Kabaya Y, Wada E (1990) Carbon isotope ratio of feathers reveals feeding behavior of cormorants. Auk 107:400-403

Mizutani H, Fukuda M, Kabaya Y (1992) ${ }^{13} \mathrm{C}$ and ${ }^{15} \mathrm{~N}$ enrichment factors of feathers of 11 species of adult birds. Eco$\operatorname{logy} 73: 1391-1395$

Nakamura I (1990) Family Gempylidae. In: Gon O, Heemstra PC (eds) Fishes of the Southern Ocean. JLB Smith Institute of Ichthyology, Grahamstown, p 402-403

Pakhomov EA (1993) Macroplankton of the waters contiguous to the Kerguelen Archipelago. In: Duhamel G (ed) Campagnes SKALP 1987 et 1988 aux îles Kerguelen à bord des navires 'SKIF' et 'KALPER'. Institut Français pour la Recherche et la Technologie Polaires, les Rapports des campagnes à la mer, Brest, 93-01:104-112

Pakhomov EA (2000) Demography and life cycle of Antarctic 
krill, Euphausia superba, in the Indian sector of the Southern Ocean: long-term comparison between coastal and open-ocean regions. Can J Fish Aquat Sci 57(Suppl 3): 68-90

Park YH (2001) Interannual sea level variability in the Southern Ocean within the context of the global climate change. AVISO Newsl 8

Park YH, Gambéroni L, Charriaud E (1993) Frontal structure, water masses, and circulation in the Crozet Basin. J Geophys Res 98:12361-12385

Perissinotto R, Pakhomov EA (1997) Feeding association of the copepod Rhincalanus gigas with the tunicate salp Salpa thompsoni in the southern ocean. Mar Biol 127: 479-483

Prince PA (1980) The food and feeding ecology of blue petrel (Halobaena caerulea) and dove prion (Pachyptila desolata). J Zool 190:59-76

Prince PA, Morgan RA (1987) Diet and feeding ecology of Procellariiformes. In: Croxall JP (ed) Seabirds. Feeding ecology and role in marine ecosystems. Cambridge University Press, Cambridge, p 135-171

Razouls C (1994) Manuel d'identification des principales espèces de copépodes pélagiques antarctiques et subantarctiques. Ann Inst Océanogr 70:3-204

Ridoux V (1994) The diets and dietary segregation of seabirds at the subantarctic Crozet Islands. Mar Ornithol 22:1-192

Ryan PG, Cooper J (1989) The distribution and abundance of aerial seabirds in relation to Antarctic krill in the Prydz Bay region, Antarctica, during late summer. Polar Biol 10: 199-209

Sabourenkov E (1992) Myctophids in the diet of Antarctic predators. Sel Sci Pap SC-CAMLR 1991:335-368

Stahl JC, Bartle JA, Jouventin P, Roux JP, Weimerskirch H (in press) Atlas of seabird distribution in the south-west Indian Ocean. Mar Ornithol

Steele WK, Klages NT (1986) Diet of the blue petrel at subAntarctic Marion Island. S Afr J Zool 21:253-256

Thompson DR, Furness RW (1995) Stable-isotope ratios of carbon and nitrogen in feathers indicate seasonal dietary shifts in northern fulmars. Auk 112:493-498

Veit RR, Hunt GL (1991) Broadscale density and aggregation of pelagic birds from a circumnavigational survey of the Antarctic Ocean. Auk 108:790-800

Editorial responsibility: Otto Kinne (Editor),

Oldendorf/Luhe, Germany
Vinogradov G (1999) Amphipoda. In: Boltovskoy D (ed) South Atlantic zooplankton. Backhuys Publishers, Leiden, p 1141-1240

Vinogradov ME, Volkov AF, Semenova TN (1996) Hyperiid amphipods (Amphipoda, Hyperiidea) of the world oceans. Science Publishers, Lebanon, NH

Warham J (1977) The incidence, functions and ecological significance of petrel stomach oils. Proc N Z Ecol Soc 24: 84-93

Warham J (1990) The petrels: their ecology and breeding systems. Academic Press, London

Waugh SM, Weimerskirch H, Cherel Y, Prince PA (2000) Contrasting strategies of provisioning and chick growth in two sympatrically breeding albatrosses at Campbell Island, New Zealand. Condor 102:804-813

Weigmann-Haass R (1983) Zur Taxonomie und Verbreitung der Gattung Cyllopus Dana 1853 (Amphipoda: Hyperiidea) im antarktischen Teil des Atlantik. 'Meteor' Forsch Ergeb D 36:1-11

Weimerskirch H, Cherel Y (1998) Feeding ecology of shorttailed shearwaters: breeding in Tasmania and foraging in the Antarctic? Mar Ecol Prog Ser 167:261-274

Weimerskirch H, Zotier R, Jouventin P (1989) The avifauna of the Kerguelen Islands. Emu 89:15-29

Weimerskirch $\mathrm{H}$, Chastel $\mathrm{O}$, Ackermann L, Chaurand $\mathrm{T}$, Cuénot-Chaillet F, Hindermeyer X, Judas J (1994) Alternate long and short foraging trips in pelagic seabird parents. Anim Behav 47:472-476

Weimerskirch H, Cherel Y, Cuénot-Chaillet F, Ridoux V (1997) Alternative foraging strategies and resource allocation by male and female wandering albatrosses. Ecology 78:2051-2063

Weimerskirch H, Fradet G, Cherel Y (1999) Natural and experimental changes in chick provisioning in a longlived seabird, the Antarctic prion. J Avian Biol 30: 165-174

Weimerskirch $\mathrm{H}$, Chastel O, Cherel Y, Henden JA, Tveraa T (2001) Nest attendance and foraging movements of northern fulmars rearing chicks at Bjørnøya, Barents Sea. Polar Biol 24:83-88

Williams R, McEldowney A (1990) A guide to the fish otoliths from waters off the Australian Antarctic Territory, Heard and Macquarie Islands. ANARE Res Notes 75:1-173

Submitted: May 31, 2001; Accepted: August 27, 2001

Proofs received from author(s): January 22, 2002 